\title{
Sorption of Ibuprofen to Coastal Plain Soils
}

By

\author{
Beau D. Benfield
}

June, 2017

Director of Thesis: Dr. Siddhartha Mitra

Major Department: Geological Sciences

\begin{abstract}
The transport and fate of pharmaceuticals and personal care products (PPCPs) in terrestrial and aquatic ecosystems has become an area of concern in the environmental science community. Due to advances in analytical technology, PPCPs have been detected in surface and groundwater at $\mathrm{ng}$ to $\mu \mathrm{g} \mathrm{L}^{-1}$ concentrations. Chronic exposure to PPCPs at these concentrations may have adverse effects on humans and aquatic organisms. The environmental fate of PPCPs is strongly influenced by their partitioning to soils, which is dependent on soil properties such as texture and organic matter content. However, few studies have examined the sorption of PPCPs to sandy, Coastal Plain soils containing low organic matter. Rapid subsurface PPCP transport may occur in Coastal Plain regions due to their characteristic permeable soils and seasonally high water tables. Laboratory batch studies were conducted in this study to evaluate the sorption of ibuprofen, a commonly used analgesic, to soils with varying physicochemical properties collected from discrete locations within North Carolina's Coastal Plain region. Sorption distribution coefficients ( $\mathrm{K}_{\mathrm{d}}$ values) were influenced by soil organic carbon content and ranged from 0.63-1.26 $\mathrm{L} \mathrm{kg}^{-1}$. Empirical organic carbon normalized sorption coefficients, $\log \mathrm{K}_{\mathrm{oc}}$, for ibuprofen in Goldsboro, Norfolk, and Lynchburg soils were compared to theoretical estimates of
\end{abstract}


its partitioning to soil organic matter (SOM). Results suggest that using such correlation equations may overestimate the partitioning of ibuprofen to SOM. 



\title{
Sorption of Ibuprofen to Coastal Plain Soils
}

\author{
A Thesis \\ Presented To the Faculty of the Department of Geological Sciences \\ East Carolina University
}

In Partial Fulfillment of the Requirements for the Degree

Master of Science in Geology

By

Beau D. Benfield

July, 2017 
(C) Beau D. Benfield, 2017 


\section{Sorption of Ibuprofen to Coastal Plain Soils}

$$
\text { By }
$$

Beau Benfield

APPROVED BY:

DIRECTOR OF

THESIS:

Siddhartha Mitra, PhD

COMMITTEE MEMBER:

Michael A. O'Driscoll, PhD

COMMITTEE MEMBER:

Alex K. Manda, PhD

COMMITTEE MEMBER:

Charles P. Humphrey Jr., PhD

CHAIR OF THE DEPARTMENT

OF GEOLOGICAL SCIENCES:

Stephen J. Culver, PhD

DEAN OF THE

GRADUATE SCHOOL:

Paul J. Gemperline, PhD 


\section{Acknowledgements}

To the many people who have assisted me in the completion of this thesis, I am sincerely grateful. I would like to give a special thanks to Dr. Siddhartha Mitra for accepting me as his graduate student, assisting me with field and lab work, and for giving me an opportunity to excel in a scientifically holistic environment. I would like to thank my committee members Dr. Alex Manda, Dr. Charles Humphrey, and Dr. Michael O’Driscoll. You all have provided me with invaluable advice and feedback during my time as a graduate student, and this thesis would not have come together the way I would have liked if it was not for your help. I would also like to

point out that none of this would have been possible without the moral and intellectual support of my colleagues here at East Carolina. I owe many thanks to John Woods and Jim Watson, two men who have been instrumental in the functionality of the East Carolina Geological Sciences department. I am certain they have impacted all of those who have studied/worked in this department, directly or indirectly. Finally, I would like to thank my mother Tiffany Vincent, and father Dwayne Benfield. If not for these two I would certainly not be who or where I am today. 


\section{TABLE OF CONTENTS}

List of Tables

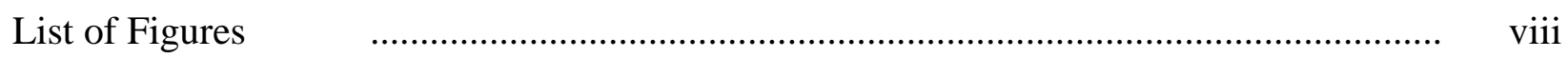

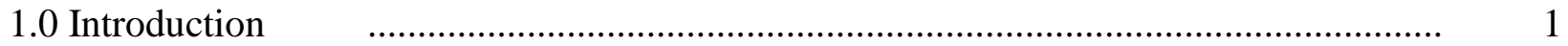

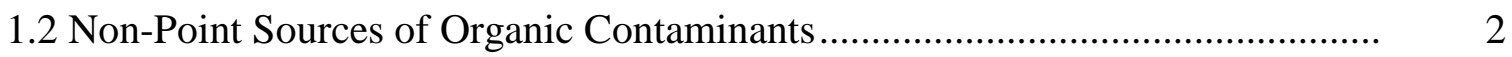

1.3 Coastal Plain Geology \& Climate............................................................. 4

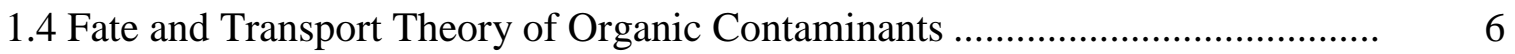

2.0 Materials \& Methods ....................................................................................... 11

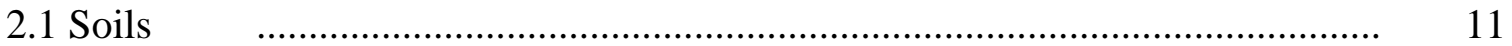

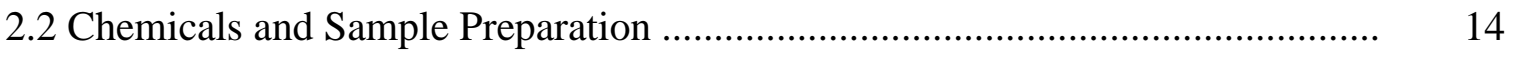

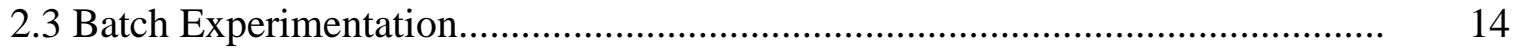

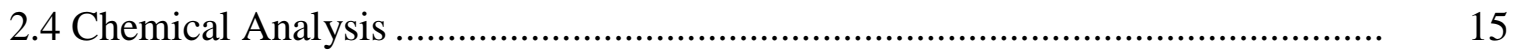

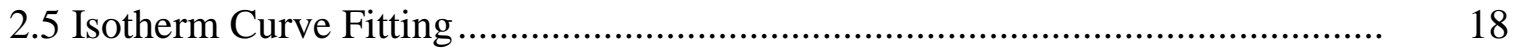

3.0 Results

3.1 Soil Physical \& Chemicals Variables ............................................................ 19

3.2 Sorption of Ibuprofen onto Coastal Plain Soils ............................................. 20

4.0 Discussion $\quad$....................................................................................... 22

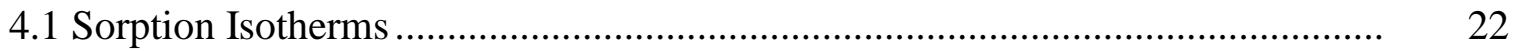

4.2 Soil Properties Controlling Mobility of Ibuprofen in Coastal Plain Soils .......... $\quad 24$

4.3 Implications for Ibuprofen Mobility in Contrasting Environments ................... 27

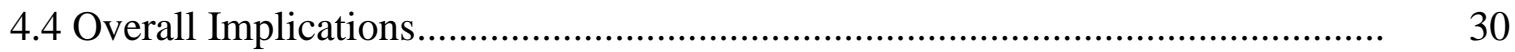




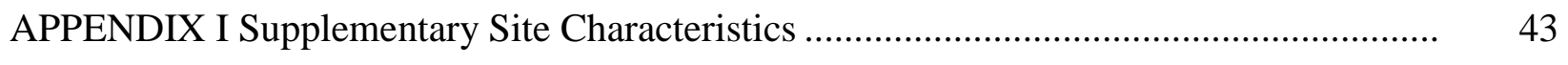

APPENDIX II Chromatograms and Mass Spectra of Compounds ........................................ 46

APPENDIX III Supplementary Soil Characteristics ………................................................. 48

APPENDIX IV Supplementary Batch Treatment Data ……………………………............ 53

APPENDIX V Calculation of Ibuprofen in Aqueous and Solid Matrices ............................ 55 


\section{LIST OF TABLES}

Table 1. Physicochemical Properties of Ibuprofen ...................................................

Table 2. ASE Parameters .................................................................................... 16

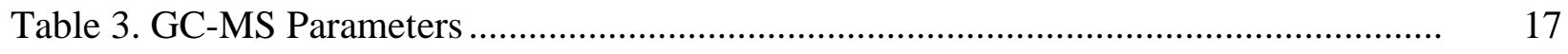

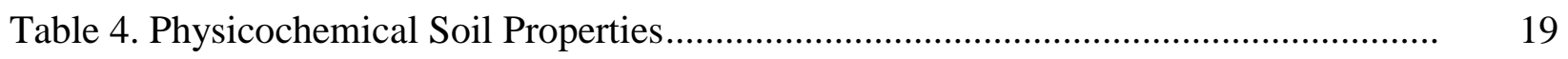

Table 5. Batch Sorption Results from Current Study .............................................. 20

Table 6. Batch Sorption Results from Other Studies ................................................. 34

Table A1. Mass Spectral Properties of Compounds ................................................. 47

Table A2. Supplementary Soil Characteristics ..................................................... 48

Table A3. Grain Size Distribution Data for Norfolk Loamy Sand ................................ 48

Table A4. Grain Size Distribution Data for Goldsboro Loamy Sand ...............................

Table A5. Grain Size Distribution Data for Lynchburg Loamy-fine Sand........................ 49

Table A6. Typical Goldsboro Loamy Sand Soil Profile ............................................. 50

Table A7. Typical Norfolk Loamy Sand Soil Profile .............................................. 51

Table A8. Typical Lynchburg Fine-Loamy Sand Soil Profile....................................... 52

Table A9. Particulate Organic Carbon Data from Batch Treatments ............................... 53

Table A10. Dissolved Organic Carbon Data from Batch Treatments ............................. 53

Table A11. Aqueous pH Data from Batch Treatments .............................................. 53

Table A12. Ibuprofen Sorption Data from Batch Experiments ................................... 54 


\section{LIST OF FIGURES}

Figure 1. Map of North Carolina's Coastal Plain ...................................................... 6

Figure 2. Conceptual Model of Freundlich Isotherms .............................................. 8

Figure 3. Conceptual Model of Sorption Mechanisms ...........................................

Figure 4. Map of Soils Used in Current Study......................................................... 13

Figure 5. Freundlich Sorption Isotherms for Goldsboro \& Norfolk Soils ........................ 21

Figure 6. Sorption Isotherm for Lynchburg Soil ................................................ 24

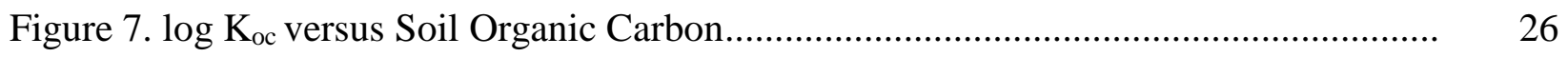

Figure 8. Soil Organic Carbon versus Ibuprofen Partition Coefficients........................... 27

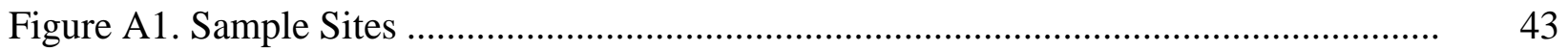

Figure A2. Depth to Water Table, Eastern North Carolina ............................................. 44

Figure A3. Soil Drainage Characteristics, Eastern North Carolina ................................. 45

Figure A4. Ibuprofen Chromatogram and Mass Spectrum......................................... 46

Figure A5. Ibuprofen- $\mathrm{d}_{3}$ Chromatogram and Mass Spectrum ...................................... 46

Figure A6. 5 $\alpha$-cholestane Chromatogram and Mass Spectrum ..................................... 47

Figure A7. Preliminary Batch Equilibration Experiment ......................................... 54 


\subsection{Introduction}

Synthetic compounds known as pharmaceuticals and personal care products (PPCPs) are ubiquitous in today's society. These compounds include the active ingredients of prescription and non-prescription drugs, cosmetics, cleansers, detergents, and fragrance products (Daughton \& Ternes 1999). Following topical application or ingestion by humans, PPCPs may be incompletely absorbed or metabolized. The result is accumulation of the compound(s) into anthropogenic waste, which is typically transported to either a centralized wastewater treatment plant (WWTP) or onsite wastewater treatment system (OWTS), also known as septic systems, before being discharged into the environment (Richardson \& Bowron, 1985; Halling-Soresnsen et al., 1998; Ternes et al., 2001). Many studies have demonstrated that WWTP and OWTS are ineffective at removing particular PPCPs from untreated sewage, permitting their entry into the surrounding environment (Halling-Sorensen et al., 1998, Daughton \& Ternes 1999). Prior studies have detected PPCPs in surface waters and groundwater at $\mathrm{ng}$ to $\mu \mathrm{g} \mathrm{L}^{-1}$ concentrations (Kolpin et al., 2002; Barnes et al., 2008; Dougherty et al., 2010; Del Rosario et al., 2014). Other possible sources of PPCPs to the environment include animal waste, landfill leachate, biosolid application, wastewater reuse for agricultural purposes and direct disposal of PPCPs into surface waters (Daughton \& Ternes 1999).

Pharmaceutical products are designed with the intent of affecting specific metabolic and molecular pathways in humans and animals. However, once these compounds and/or their metabolites enter the natural environment, they may induce unintended effects on terrestrial and aquatic non-target organisms (Daughton \& Ternes, 1999). For example, trace levels of ibuprofen have been shown to induce genetic and systemic damage to certain mussel and fish species, as well as human fetal testes (Ericson et al., 2010; Han et al., 2010; Maamar et al., 2017). Despite 
low environmental concentrations, the adverse health effects that PPCPs may have on humans and other organisms as a result of chronic exposure are not well understood (Sipma et al., 2010). Soils and sediments are a primary repository for xenobiotic compounds that are released into the environment (Wu \& Gschwend 1986). The mobility of PPCPs associated with wastewater percolating through the subsurface is highly dependent on their potential to sorb (adsorb onto a surface, or absorb into a matrix) to soil. The fraction of organic carbon $\left(f_{o c}\right)$ in soil is an important constituent that enhances sorption of nonpolar and slightly polar organic contaminants from the aqueous phase (Karickhoff 1984). Other factors that influence sorption and degradation of PPCPs are soil and groundwater $\mathrm{pH}$, soil cation exchange capacity (CEC), grain size, and microbial respiration (Yamamoto et al., 2009; Xu et al., 2009; Estevez et al., 2014). Because of their potentially adverse effects on aquatic and terrestrial organisms, understanding attenuation mechanisms of PPCPs in subsurface environments is pertinent to assessing their environmental fate and mobility.

\subsection{Wastewater Reclamation \& OWTS: Non-Point Sources of PPCPs.}

Solid byproducts produced by municipal wastewater treatment processes that undergo additional treatment in order to meet regulatory standards are referred to as biosolids (Kinney et al., 2006). In North Carolina and the United States, land application of biosolids is the prevailing method of biosolid management (Keil et al., 2011). Biosolids are rich in nutrients and organic carbon, and are used extensively in the agriculture industry as a soil amendment to enhance crop yields (Kinney et al., 2006). It has been estimated that more than $8 \mathrm{M}$ dry tons of biosolids are

produced in the United States every year (McClellan \& Halden 2010). In 2008, North Carolina activated 148 permits in 76 counties, allowing land application of biosolids for agricultural purposes (Keil et al., 2011). 
Although biosolids may possess beneficial soil amendment characteristics, they also contain an array of organic contaminants, including PPCPs (Kinney et al., 2006). A study conducted by McClellan and Halden (2010) analyzed the occurrence of PPCPs in biosolid samples obtained from 94 WWTP across the United States. In that study, ibuprofen was detected in $80 \%$ of the biosolid samples tested at a mean concentration of $246 \mu \mathrm{g} \mathrm{kg}^{-1}$. Following land application of biosolids, ibuprofen has the potential to leach into the underlying soil where it may be wholly or partially attenuated before reaching groundwater or surface water (Xia et al., 2005).

Another common source of PPCPs to the aquatic environment are OWTS. In rural regions of the United States, OWTS are the most common method of wastewater treatment (U.S. EPA, 2002). According to the US EPA (2002), approximately 23\% of the US population utilizes OWTS for wastewater management. OWTS release approximately 1,460 billion gallons of effluent annually in the United States (U.S. Census Bureau, 1999). In North Carolina, 40,000 new OWTS are installed each year, adding to the 1,440,000 OWTS already in use (NC DEHNR, 1996). OWTS typically consist of three primary constituents: septic tank, drain field trench, and the underlying soil. In the septic tank, raw wastewater is separated into solids and liquids. The solids settle to the bottom of the tank, where bacterial transformation takes place. The liquid phase of the waste migrates to a drain field located adjacent to the tank. A properly functioning drain field typically consist of underground perforated pipes that lead to homogenous distribution of the liquid waste into the underlying soil. It is here in the soil beneath the drain field trench that the majority of physical, chemical, and biological treatment to wastewater effluent occurs (U.S. EPA, 2002). When properly designed and implemented, OWTS can be an effective means of wastewater treatment. However, improperly installed, maintained or poorly-functioning septic systems and/or improper installation of septic systems may result in inadequate attenuation of 
anthropogenic contaminants before they reach receiving surface or groundwater. This is especially true in regions characteristic of sandy, permeable soils low in organic matter, such as North Carolina's Inner Coastal Plain (Figure 1). For example, Del Rosario et al. (2014) detected ibuprofen at a concentration of $0.24 \mu \mathrm{g} \mathrm{L}^{-1}$ in an Inner Coastal Plain stream located $52 \mathrm{~m}$ away from a home(s) utilizing OWTS. This raises concern because exposure to ibuprofen at trace concentrations has been demonstrated to adversely affect reproductive functions in both humans and aquatic organisms (Han et al., 2010; Kristensen et al., 2016; Maamar et al., 2017). Hence, it is pertinent to understand sorption mechanisms that may govern the attenuation of ibuprofen in soils underlying and adjacent to OWTS.

\subsection{Coastal Plain Geology \& Climate}

The Coastal Plain of the eastern United States is both an erosional and depositional terrain of Holocene-Cretaceous age, consisting primarily of siliceous sedimentary parent material derived from previous marine transgressions (Daniels et al., 1978). These sedimentary deposits dip slightly toward the Atlantic Ocean at a slope of approximately 0.001 , and are underlain by crystalline bedrock (Winner \& Coble 1996). Individual deposits range in thickness from $0 \mathrm{~m}$ at the fall line to approximately 3,000 m at Cape Hatteras (Winner \& Coble 1996). Intensely leached and acidic Ultisols are the dominant soil order of the region (Markewich et al., 1990). Ultisols also cover approximately $9.2 \%$ of the total US land area and support $18 \%$ of the world's population (Miller 1983). Infiltration rates for Coastal Plain soils are generally $13-28 \mathrm{~cm} \mathrm{~h}^{-1}$. However, unconsolidated quartz sand deposits may exhibit infiltration rates that exceed $50 \mathrm{~cm} \mathrm{~h}^{-1}$ (Markewich et al., 1990). To put this in perspective, North Carolina Piedmont soils typically have infiltration rates on the order of 6-15 $\mathrm{cm} \mathrm{h}^{-1}$ (Markewich et al., 1990). 
North Carolina's Coastal Plain can be divided into the Inner and Outer Coastal Plain by the Suffolk Scarp (Stuckey 1965) (Figure 1). Topography in the Outer Coastal Plain is relatively flat (average topographic relief is approximately $6 \mathrm{~m}$ ). Moving inland from the scarp, there is a general increase in elevation, with rolling hills reaching $60 \mathrm{~m}$ above sea level (average topographic relief of Inner Coastal Plain is approximately 70 m) (Soller \& Mills, 1991).

Although Inner and Outer Coastal Plain soils can be mineralogically similar, they can be drastically different when considering soil organic matter (SOM). Minimal topographic relief and moderate precipitation may yield large deposits of SOM in the Outer Coastal Plain, while Inner Coastal Plain soils typically possess little SOM due to greater topographic relief and soil maturity (Daniels \& Gamble 1970). For example, upper soil horizons in the Outer Coastal Plain commonly have 15\% SOM, while Inner Coastal Plain soils may contain 5\% SOM (Tesoriero et al., 2004). Another significant difference between the two regions are soil drainage characteristics. Spruill et al. (1997) approximated that 45\% of North Carolina's Inner Coastal Plain soils are well-drained to moderately well-drained, while only $17 \%$ of the Outer Coastal Plain soils are well drained to moderately-well drained. Thus, areas characteristic of rapid groundwater infiltration rates and minimal SOM, such as North Carolina's Inner Coastal Plain, may be prone to rapid subsurface pharmaceutical transport.

Over the past decade, the climate of North Carolina's Coastal Plain region has been humid and temperate to sub-tropical, with annual air temperatures ranging from $14.5-20.0^{\circ} \mathrm{C}$. Average precipitation and evapotranspiration rates range from 100-175 $\mathrm{cm} \mathrm{yr}^{-1}$ and $90-150 \mathrm{~cm}$ $\mathrm{yr}^{-1}$, respectively (NOAA 2016). The water table in North Carolina's Coastal Plain is generally highest during winter months, when evapotranspiration is minimal (Sun et al., 2002). Local, loworder streams of the Coastal Plain typically have low $\mathrm{pH}$ values $(\leq 5)$, and concentrations of 
dissolved organic carbon (DOC) ranging from 10-30 $\mathrm{mg} \mathrm{L}^{-1}$ (Horton 1945). This is important to note because DOC has been shown to facilitate the transport of aqueous-phase PPCPs (Hernandez-Ruiz et al., 2012).

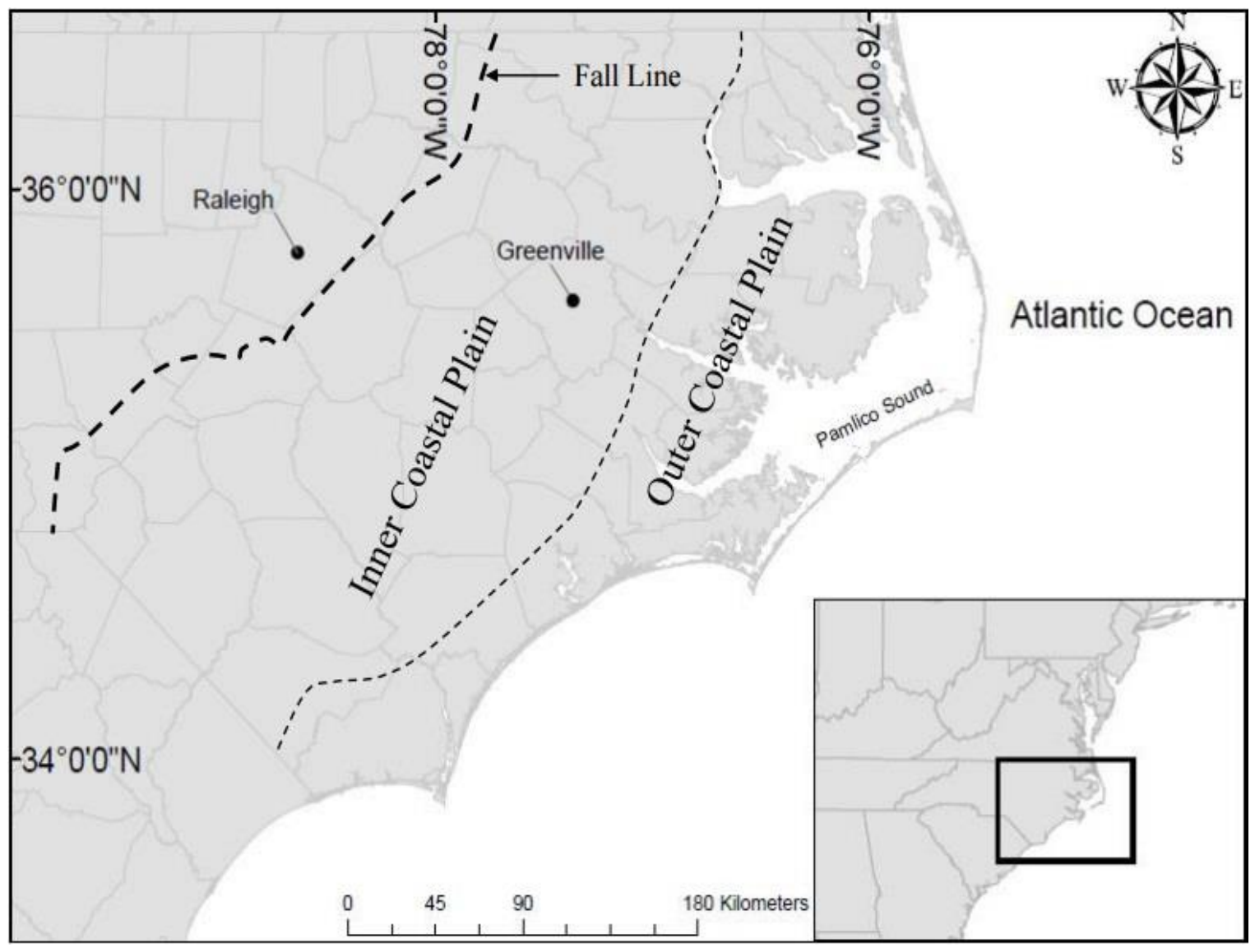

Fig. 1. Map of North Carolina's Inner and Outer Coastal Plain. Dotted line between Inner and Outer Coastal Plain shows the approximate location of the Suffolk Scarp.

\subsection{Fate and Transport Theory}

Ibuprofen is an archetypical non-steroidal, anti-inflammatory drug (NSAID) frequently used in the treatment of rheumatic disorders, pain, and fever. The molecular structure and other selected properties of ibuprofen are shown in Table 1. Ibuprofen is typically consumed in relatively high therapeutic dosages (1200-1600 mg per person per day). Approximately $60 \%$ of ingested ibuprofen is excreted in the form of the parent compound and/or its metabolites (Mills 
1973). The extent to which ibuprofen is mobile in the aquatic environment is equivocal. For example, Ternes et al. (2002) suggest that ibuprofen should significantly adsorb to SOM due to its $\log$ octanol-water partition coefficient $\left(\log \mathrm{K}_{\mathrm{ow}}\right)$ of 3.97. Conversely, Cho et al. (2011) suggest that ibuprofen's solubility in water of $21 \mathrm{mg} \mathrm{L}^{-1}$ renders it to be highly mobile in the aquatic environment.

\begin{tabular}{lllll}
\hline Table 1. Physicochemical properties of ibuprofen & & & \\
\hline PPCP & $\begin{array}{c}\text { Molecular } \\
\text { Weight } \\
\left(\mathrm{g} \mathrm{mol}^{-1}\right)\end{array}$ & $\begin{array}{c}\text { Water } \\
\text { Solubility } \\
\left(\mathrm{mg} \mathrm{L}^{-1}\right)\end{array}$ & Log Kow $_{\text {ow }}$ & pKa \\
\hline Ibuprofen & 206.3 & $21^{\mathrm{a}}$ & $3.97^{\mathrm{b}}$ & $4.9^{\mathrm{c}}$ \\
\end{tabular}

${ }^{a}$ Yalkowsky \& Dannenfelser, 1992

${ }^{b}$ Avdeef et al., 1998

${ }^{\mathrm{c}}$ Sangster, 1989

The distribution of ibuprofen between solid and aqueous phases is directly related to its aqueous solubility as well as its ability to dissolve into non-polar organic phases associated with environmental solids (e.g. soils and sediments). The distribution of ibuprofen between a solid and liquid phase at equilibrium can be conceptualized with Equation 1 below,

$$
\mathrm{K}_{\mathrm{d}}=\mathrm{C}_{\mathrm{s}} / \mathrm{C}_{\mathrm{w}}
$$

where $\mathrm{C}_{\mathrm{s}}$ is the concentration of ibuprofen in the solid phase, $\mathrm{C}_{\mathrm{w}}$ the concentration in the liquid phase, and $K_{d}$ is the distribution coefficient. 
Sorption isotherms, which depict the distribution coefficient of a compound between solid and liquid phases within a soil type, can be used to graphically depict the equilibrium distribution of ibuprofen between the solid and aqueous phase in a soil/water matrix. In this study, $\mathrm{K}_{\mathrm{d}}$ values from laboratory batch experiments were used to determine sorption isotherms of ibuprofen in three Coastal Plain soils (Norfolk loamy sand, Lynchburg loamy fine-sand, and Goldsboro loamy sand). Empirical sorption data for ibuprofen were fit to Freundlich isotherms (Figure 2) to better understand the distribution of ibuprofen in Coastal Plain soils.

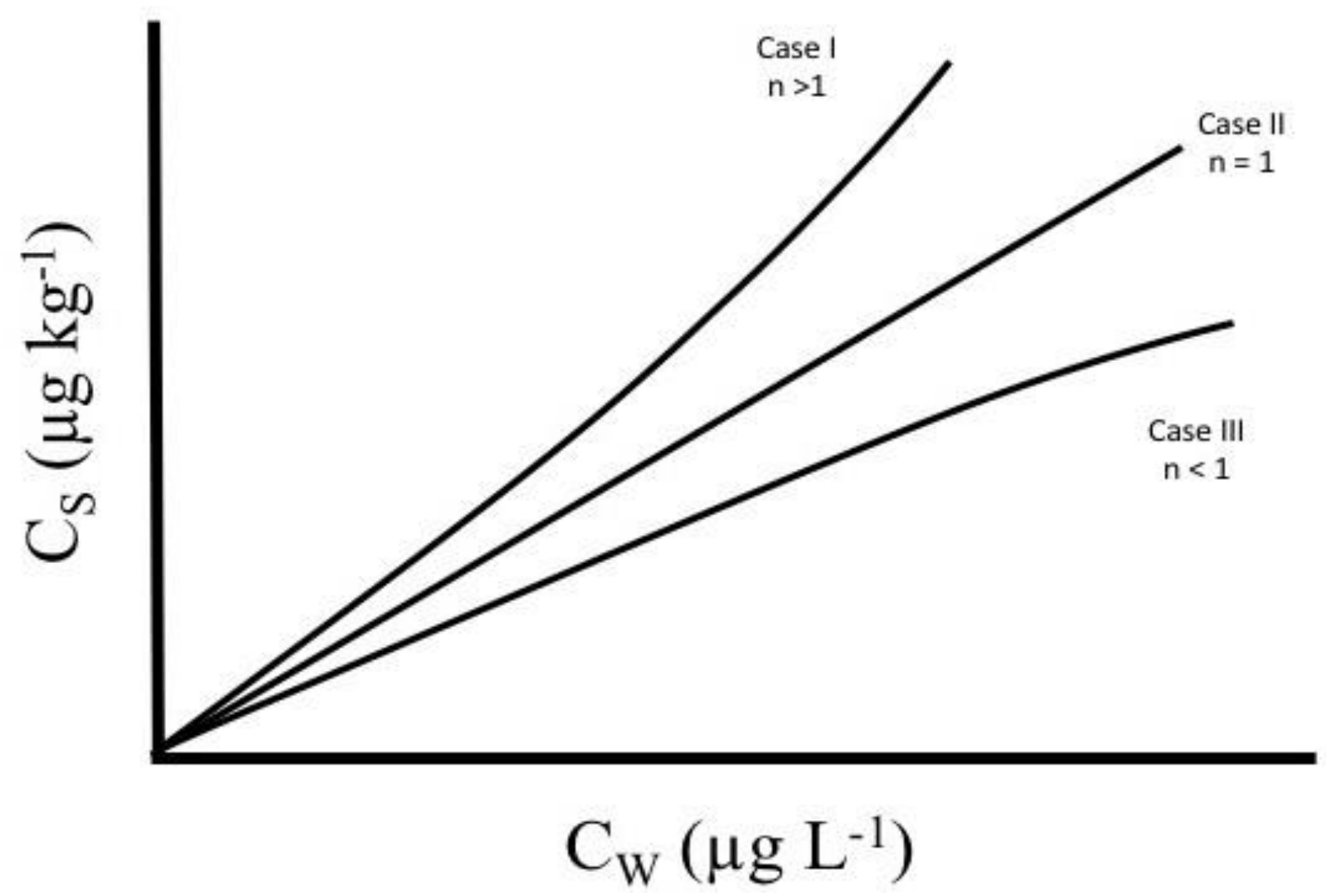

Fig. 2. Schematic diagram of Freundlich Isotherms. $C_{s}$ is concentration of sorbate (dissolved compound) in solid phase and $\mathrm{C}_{\mathrm{w}}$ the concentration of sorbate in aqueous phase. Case I indicates a situation where an increase in sorbate concentration results in an increase in sorption of the sorbate molecule. Case II describes a situation where the sorption affinity of the sorbate for the solid phase remains the same for all aqueous concentrations. Case III reflects a situation where an increasing sorbate concentration decreases the sorption potential of the solid phase. Each isotherm can be fit with the equation $\mathrm{C}_{\mathrm{s}}=\mathrm{KC}_{\mathrm{w}}{ }^{\mathrm{n}}$, where $\mathrm{K}$ and $\mathrm{n}$ are constants. 
The transformation and fate of ibuprofen in soil affects its potential for ground and surface water pollution (Dodgen et al., 2014). During subsurface transport, ibuprofen has the potential to adsorb to SOM and/or mineral surfaces present in soil (Figure 2). Such adsorption may result in attenuation of ibuprofen and reduce subsequent down-gradient transport. However, not all soil profiles are equally effective in pollutant attenuation (Foster and Chilton, 2003).

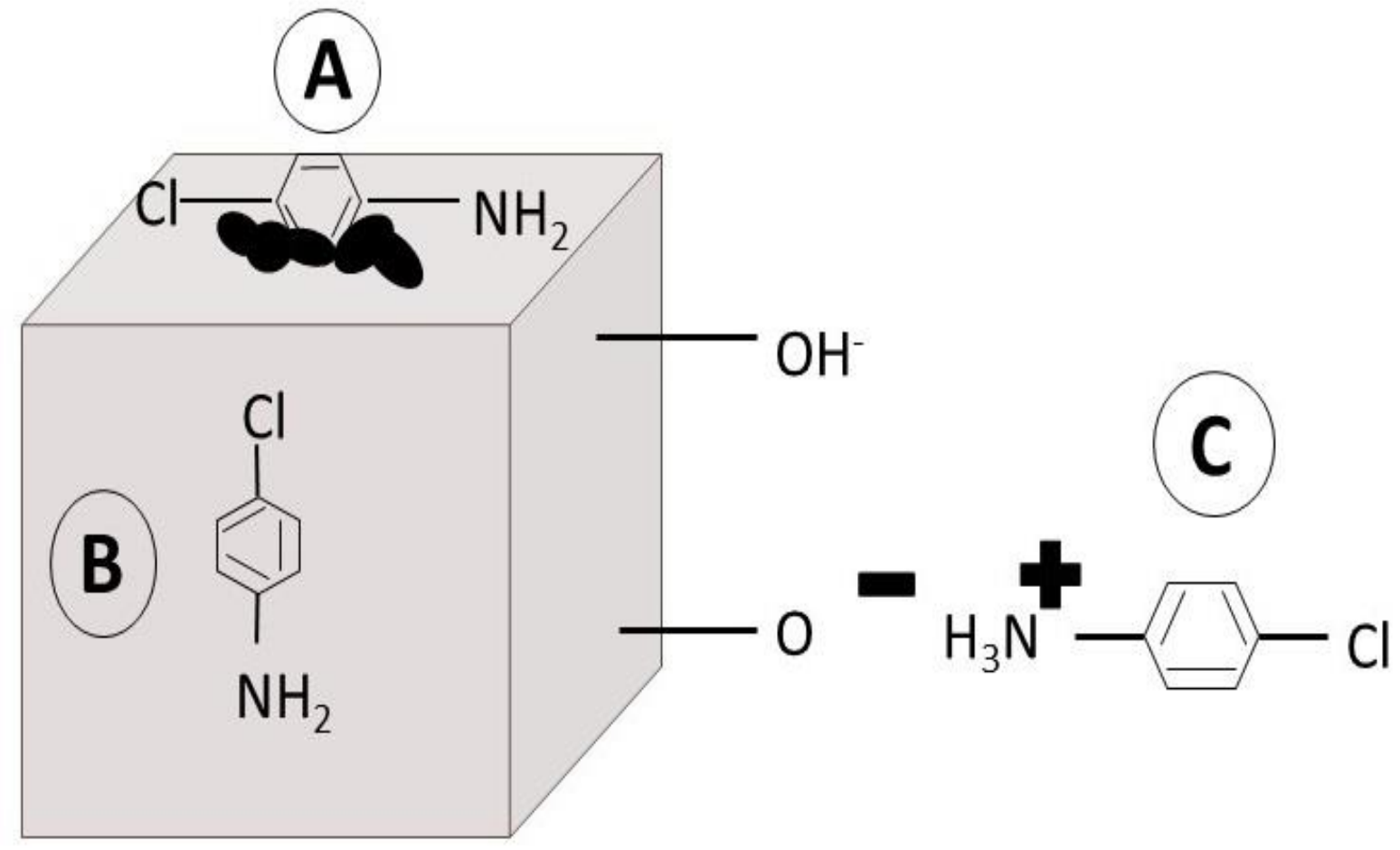

Fig. 3. Processes that may attenuate PPCPs as they migrate through the soil profile: A) Neutral sorbate (dissolved compound) escapes water into natural organic matter (depicted as small black elliptical solids). B) Sorbate adsorbs onto sediment (sorbent) surface. C) Charged sorbate electrostatically attracted to oppositely-charged surface sites (Figure modified from Schwarzenbach et al., 1993).

Natural organic constituents associated with soil minerals or suspended in the liquid phase are favorable sorption sites for ibuprofen dissolved in the aqueous phase (Chiou et al., 
1979). In contrast to charged mineral surfaces, SOM is relatively nonpolar. From a free-energy point of view, charged surfaces of soil minerals strongly favor interactions with polar compounds, such as liquid water. In contrast, relatively nonpolar SOM would generally interact with relatively neutral compounds, such as ibuprofen. Thus, when analyzing the partitioning of aqueous-phase ibuprofen in the environment, it is important to consider the amount of organic material present in the solid (i.e. sediment or soil) phase (Chiou et al., 1979).

This study was conducted to determine the impact SOM and aqueous concentration of ibuprofen have on its partitioning to sandy Coastal Plain soils. Numerous studies have focused on the sorption of ibuprofen in soil and sediment (Scheytt et al., 2005, Yamamoto et al., 2009, Xu et al., 2009, Estevez et al., 2014, Styszko et al., 2010, Vulava et al., 2016). However, no known studies exist that examine the sorption of ibuprofen to Coastal Plain soils with low SOM. I hypothesize that ibuprofen is more likely to partition to soils with greater SOM because of its nonpolar moiety. I also hypothesize that as the aqueous concentration of ibuprofen increases, available soil sorption sites will become occupied, resulting in a decreased affinity of ibuprofen for the solid phase. 


\subsection{Materials and Methods}

\subsection{Soils}

Samples of three mineral soils were collected in January, 2016, from Pinetops, NC, USA. Five samples were collected for each soil type from discrete locations and were subsequently homogenized to create a composite sample for each soil (discrete sampling locations are shown in Appendix I. Supplementary Site Characteristics). The soils: Goldsboro loamy sand, Norfolk loamy sand, and Lynchburg loamy-fine sand, were selected based on their geographic extent throughout the southeastern United States (Figure 4). Duffera et al. (2007) found that these three soils make up millions of hectares of farmland throughout the southeastern US. Also, Del Rosario et al. (2014) detected ibuprofen in surface waters of the Inner Coastal Plain, adjacent to homes utilizing septic systems underlain by Goldsboro and Lynchburg soils, providing evidence of ibuprofen subsurface abundance and mobility through these soils.

Soil samples were taken at a depth of $3-30 \mathrm{~cm}$ beneath the ground surface using a stainless-steel trowel and stored in paper bags until further processing at the laboratory. Prior to excavation, the upper $3 \mathrm{~cm}$ of each sample was removed to minimize the presence of decaying crop matter. In situ observations of extracted soil profiles showed no sign of an $\mathrm{O}$ horizon. This agrees with United States Department of Agriculture (USDA) data that indicates Goldsboro, Norfolk, and Lynchburg soil series all have an Ap horizon (A horizon that has been plowed) present from 0 to approximately $18 \mathrm{~cm}$ beneath the land surface. The Ap horizon is underlain by an E horizon that extends to approximately $30 \mathrm{~cm}$ beneath the land surface (Appendix III. Supplementary Soil Characteristics). Therefore, soils used in this study were collected from the Ap and E horizons. Because this was a plowed field, it is likely that little organic material was lost at the expense of removing the top layer of decaying plant matter. Once in the laboratory, soils were allowed to air dry for $24 \mathrm{~h}$. Soils were then sieved to remove particles greater than 2 
$\mathrm{mm}$ (particles this large were very rare) in diameter, and placed in amber glass jars until further analysis. Nitrile gloves were worn while handling samples or their extracts. All glassware used in experiments was cleaned by heating at $450^{\circ} \mathrm{C}$ for $4 \mathrm{~h}$.

Chemical properties of soils (Table 4) were determined by sending a subsample of each soil to the North Carolina Department of Agricultural and Consumer Services (NCDA\&CS) Agronomic Division and the Yale University Stable Isotope Center (YASIC). Grain size was determined by sieve analysis. Particles with diameters $>0.25 \mathrm{~mm}$ were considered medium sand, particles with diameters $<0.25 \mathrm{~mm}$ and $>0.06 \mathrm{~mm}$ were considered fine sand, and particles with diameters $<0.06 \mathrm{~mm}$ were considered silt/clay (Appendix III. Supplementary Soil Characteristics). 


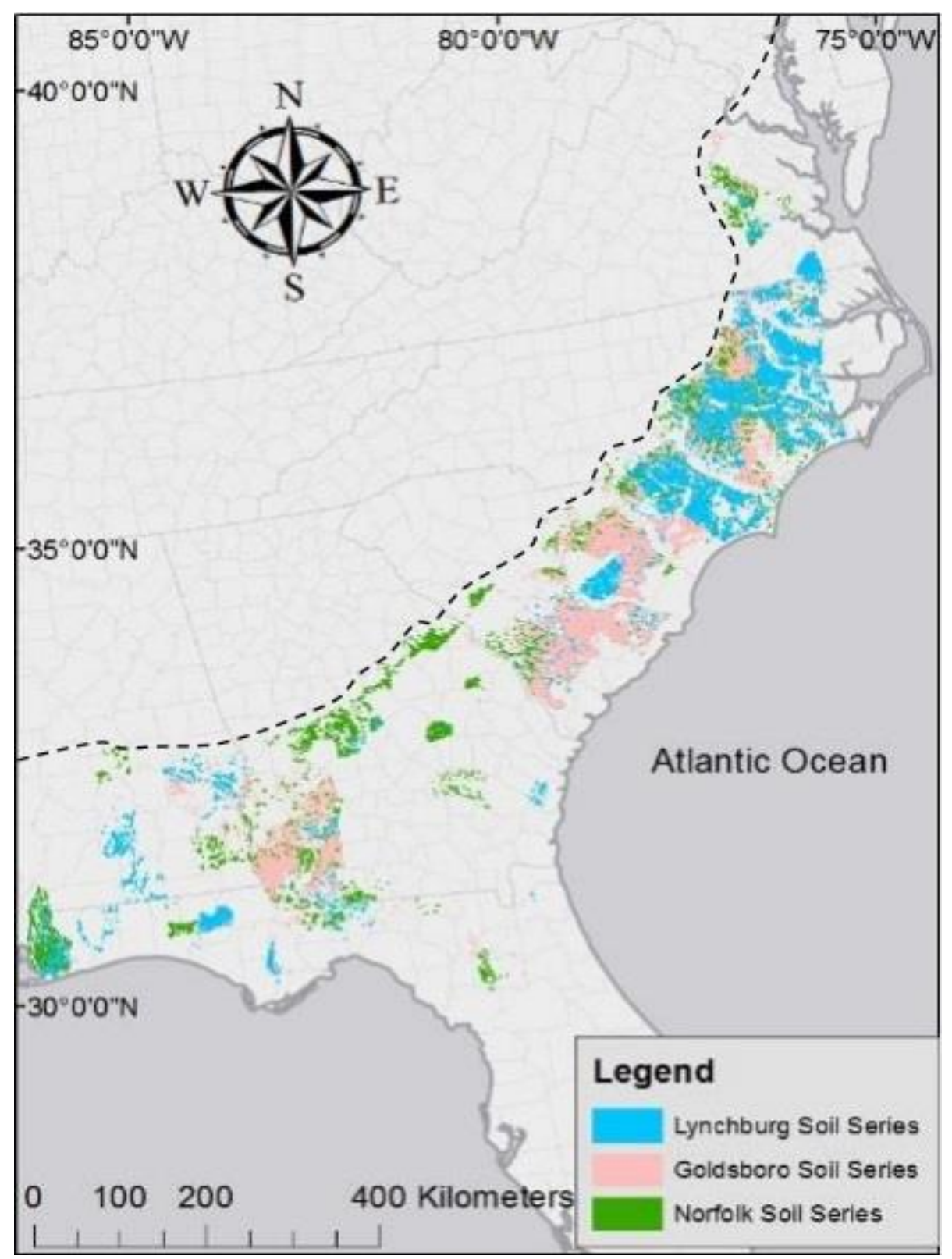

Fig. 4. Map of southeastern United States showing spatial distribution of soils used in the current study. Black dashed line represents the approximate location of the Coastal Plain-Piedmont boundary, also known as the "fall line". Data obtained from USDA Natural Resources Conservation Service (2016). 


\subsection{Chemicals and Sample Preparation}

Solid ibuprofen ( $\geq 99 \%$ purity) was obtained from Arcos Organics, New Jersey, USA. Solid ibuprofen- $\mathrm{d}_{3}(\geq 98 \%$ purity) and $5 \alpha$-cholestane ( $\geq 97 \%$ purity) were used as surrogate and internal standards, respectively, and were purchased from Sigma-Aldrich (St. Louis, MO, USA). Bis(trimethylsilyl)trifluoroacetamide (BSTFA), used as a derivatizing agent, was purchased from Thermo Scientific (Bellefonte, PA, USA). All solvents used in this study were of analytical grade; solvents were purchased from EMD Millipore (Billerica, MA, USA).

A stock solution of the target compound was created by dissolving solid ibuprofen in 100 $\mathrm{mL}$ of methanol. A stock solution of ibuprofen- $\mathrm{d}_{3}\left(1,000 \mu \mathrm{g} \mathrm{g}^{-1}\right)$ was prepared by dissolving approximately $20 \mathrm{mg}$ of ibuprofen- $\mathrm{d}_{3}$ in $25 \mathrm{~mL}$ of methanol. A stock solution of $5 \alpha$-cholestane $\left(1,200 \mu \mathrm{g} \mathrm{g}^{-1}\right)$ was prepared by dissolving approximately $19 \mathrm{mg}$ of $5 \alpha$-cholestane in $25 \mathrm{~mL}$ of hexane. Working solutions of ibuprofen in methanol were prepared from the stock solution at four separate concentrations $\left(1,024.70 \mu \mathrm{g} \mathrm{L}^{-1}, 3,181.00 \mu \mathrm{g} \mathrm{L}^{-1}, 5,669.10 \mu \mathrm{g} \mathrm{L}^{-1}\right.$, and 11,667.80

$\mu \mathrm{g} \mathrm{L}^{-1}$ ). A relative response factor (RRF) solution was created by combining the target compound, surrogate and internal standard into a $50 \mathrm{~mL}$ volumetric flask.

\subsection{Batch Experiment}

For sorption experiments, $4.80 \pm 0.01 \mathrm{~g}$ of soil was weighed and placed in glass centrifuge tubes; next $6.00 \pm 0.01 \mathrm{~g}$ of distilled de-ionized (DDI) water was added (soil:solution ratio was 4:5). According to Scheytt et al. (2005), a soil to solution ratio of 4:5 is representative of natural conditions in the unsaturated zone. The water/soil mixture was then spiked with approximately $0.70 \mathrm{~g}$ of ibuprofen working solution. Test tubes were then capped with Teflon lids and agitated on an orbital shaker at $9 \mathrm{rpm}$ for $24 \mathrm{~h}$; agitation was performed in the dark to minimize photodegradation of ibuprofen. Preliminary experiments suggested that $24 \mathrm{~h}$ was 
adequate time for the soil/water solution to reach equilibrium (Appendix IV. Supplementary

Batch Treatment Data). Following agitation, samples were centrifuged at $250 \mathrm{rpm}$ for $15 \mathrm{~min}$ to separate the soil and liquid phases. The supernatant was then filtered through $47 \mathrm{~mm}$ glass fiber filters to remove any remaining particulates. Following filtration, samples were stored at $4^{\circ} \mathrm{C}$ until further analysis. Preliminary experiments were conducted to determine the soil solution $\mathrm{pH}$ of batch treatments following $24 \mathrm{~h}$ of agitation on the orbital shaker (Appendix IV.

Supplementary Batch Treatment Data). Also, the concentration of DOC and particulate organic carbon (POC) of water from batch treatments were determined (Appendix IV. Supplementary Batch Treatment Data). All batch treatments were conducted at ambient temperatures of $21^{\circ} \mathrm{C} \pm$ $1^{\circ} \mathrm{C}$.

\subsection{Chemical Analysis}

Ibuprofen was extracted from solid and aqueous matrices using accelerated solvent extraction (ASE) and liquid-liquid extraction (LLE), respectively. Ibuprofen in each phase was quantified using a Shimadzu QP5050 gas chromatograph-mass spectrometer (GC-MS), operated in selected ion monitoring (SIM) mode. The surrogate, internal, and target compounds were identified using two degrees of confirmation: retention time and the mass fragmentation pattern of each compound. Compounds were not quantified unless their signal-to-noise ratio exceeded $7: 1$.

Ibuprofen concentrations in the solid phase were determined using a Dionex 350 ASE. Experimental parameters for ASE are listed in Table 2. Prior to analysis, samples were allowed to dry in an oven at $60^{\circ} \mathrm{C}$ for approximately $24 \mathrm{~h}$. Samples were weighed before drying, after 20 $\mathrm{h}$ of drying, and after $24 \mathrm{~h}$ of drying to determine the soils dry weight. Next, a known mass of dry soil was placed in a $10 \mathrm{~mL}$ stainless steel extraction cell. A $47 \mathrm{~mm}$ glass fiber filter was 
placed at the effluent end of the ASE cell to prevent solids from leaching into the collection vial. Following extraction, samples were transferred to rotovap flask and prepared for GC-MS analysis. For LLE, dichloromethane (DCM) was used as the organic solvent. The DCMsupernatant mixture was agitated for 3 min and allowed to separate. The DCM fraction was then transferred to a glass rotary evaporation (rotovap) flask. Each sample was then concentrated to approximately $1 \mathrm{~mL}$ and transferred to a glass conical tube where it was blown to dryness under a steady stream of nitrogen. Prior to derivatization, approximately $0.5 \mathrm{~mL}$ of pyridine and 0.1 mL of BSTFA were added to each sample. Derivatization was performed in a heated water bath set at $70^{\circ} \mathrm{C}$ for $90 \mathrm{~min}$. Derivatization increases ibuprofen's volatility and decreases its polarity by replacing its active hydrogen atom with a less polar trimethylsilyl group. The result is a modified form of ibuprofen that is more amendable to gas chromatography (Danielson et al., 2000). Following derivatization, samples were capped and placed on the Shimadzu AOC-20i Auto Injector, where $2 \mu \mathrm{L}$ of the sample was injected. Specific GC-MS parameters used for this study are listed in Table 3.

\begin{tabular}{cccc}
\hline Table 2. ASE Parameters & & \\
\hline Solvent & $\begin{array}{c}\text { Oven Temperature } \\
\left({ }^{\circ} \mathrm{C}\right)\end{array}$ & $\begin{array}{c}\text { Static } \\
\text { Cycles }\end{array}$ & $\begin{array}{c}\text { Purge Time } \\
(\mathrm{sec})\end{array}$ \\
Acetone:Hexane $(1: 1, v: v)$ & 150 & 3 & 90 \\
\hline
\end{tabular}




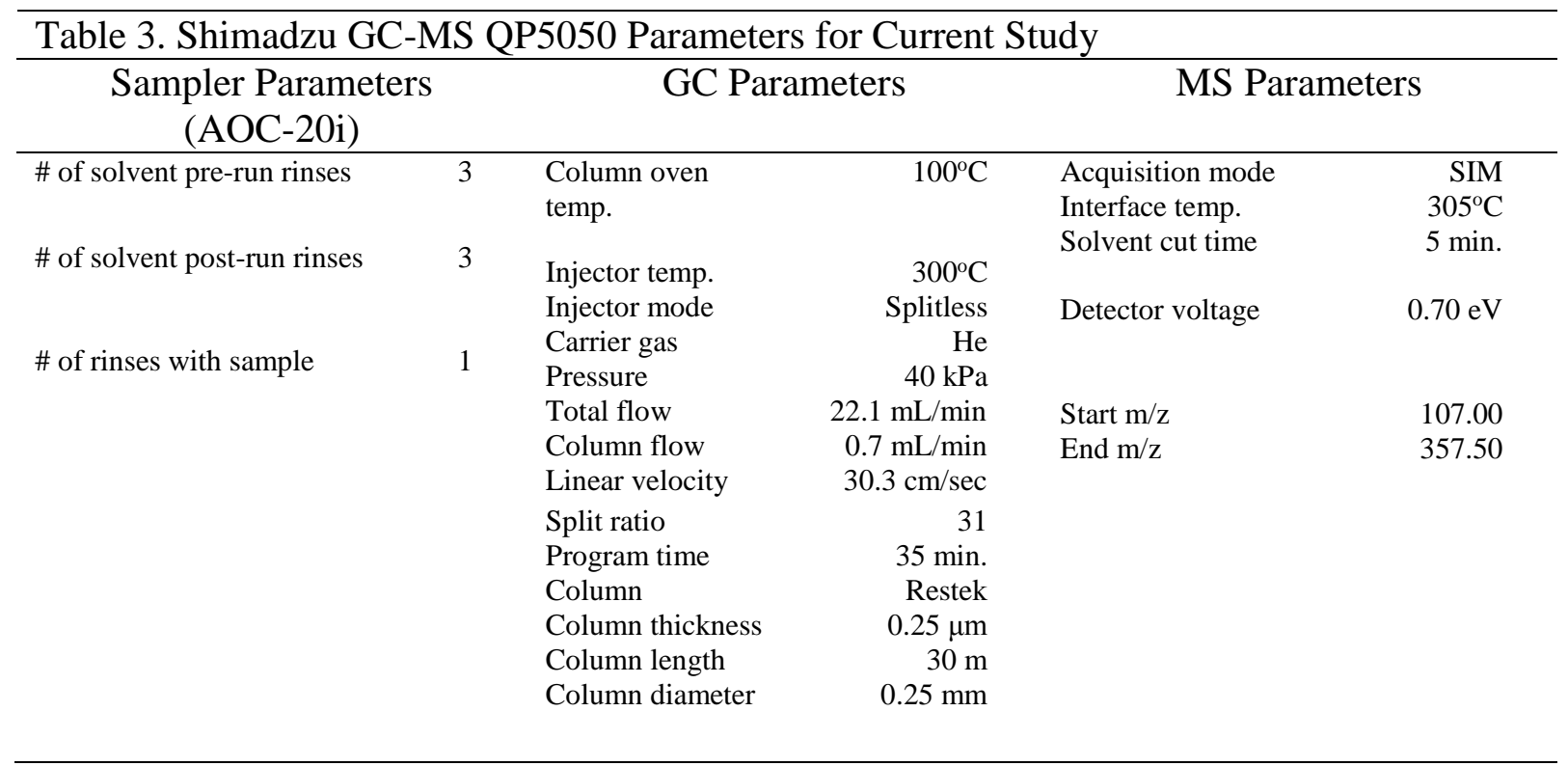

A calibration solution containing known concentrations of ibuprofen, the internal standard, and surrogate standard was used for the identification and quantification of ibuprofen in liquid and solid extracts. This calibration solution was injected into the GC-MS in order to determine the detector's response to ibuprofen relative to the surrogate standard, also known as the relative response factor (RRF). The percent of ibuprofen recovered during the extraction process was calculated based on the amount of surrogate standard recovered, relative to the amount of internal standard recovered (Appendix V. Calculation of Ibuprofen in Aqueous and Solid Matrices). 


\subsection{Isotherm Curve-Fitting}

Sorption isotherms were fit with the Freundlich equation to explain the relationship between concentrations of ibuprofen in solution and the concentration sorbed to soil at equilibrium:

$$
\mathrm{C}_{\mathrm{s}}=\mathrm{KC}_{\mathrm{w}}{ }^{\mathrm{n}}
$$

(Equation 2)

where $C_{s}$ and $C_{w}$ are the concentrations of ibuprofen in the solid and liquid phase, respectively. $\mathrm{K}$ is referred to as the Freundlich constant and $\mathrm{n}$ is a constant indicative of the nonlinearity involved (Schwarzenbach et al., 1993).

Ibuprofen sorption coefficients across different soils were compared by scaling the $\mathrm{K}_{\mathrm{d}}$ to $f_{o c}$ in soil,

$$
\mathrm{K}_{\mathrm{oc}}=\mathrm{K}_{\mathrm{d}} / f_{o c}
$$

where $\mathrm{K}_{\mathrm{oc}}$ is the organic-carbon normalized sorption coefficient. Three equations (equations 1, 2, and 3) were used for conceptualizing distributions of ibuprofen between the solution and solid phase in order to compare data with similar studies, and to determine the impact that SOM has on the sorption of ibuprofen to Coastal Plain soils. 


\subsection{Results}

\subsection{Soil Physical and Chemical Variables}

The bulk physical and chemical properties of the soils studied are shown in Table 4.

Goldsboro sandy loam had the highest $f_{o c}$, percent humic matter, and percent of silts and clays.

Soil bulk density, $\mathrm{CEC}$, and $\mathrm{pH}$ were similar for all soils, implying that these variables had minimal to no influence on any potential observed differences in ibuprofen sorption. Grain size analysis revealed that soils were texturally similar (loamy sand); however, the Lynchburg soil did have higher percentages of sand than the other two soils.

\begin{tabular}{|c|c|c|c|}
\hline & Norfolk & Goldsboro & Lynchburg \\
\hline$\%$ Humic Matter ${ }^{\mathrm{a}}$ & 0.32 & 0.41 & 0.36 \\
\hline Density $\left(\mathrm{g} \mathrm{cm}^{-3}\right)^{\mathrm{a}}$ & 1.49 & 1.42 & 1.55 \\
\hline $\operatorname{CEC}\left(\mathrm{meq} 100 \mathrm{~cm}^{-3}\right)^{\mathrm{a}}$ & 3.5 & 3.3 & 2.5 \\
\hline $\mathrm{pH}^{\mathrm{a}}$ & 5.2 & 5.0 & 5.4 \\
\hline$f_{\text {oc }}\left(\mathrm{kg} \mathrm{kg}^{-1}\right)^{\mathrm{b}}$ & $3.7 \times 10^{-3}$ & $7.9 \times 10^{-3}$ & $2.0 \times 10^{-3}$ \\
\hline$\%$ Medium-Coarse Sand ${ }^{\mathrm{c}}$ & 42.71 & 31.05 & 50.74 \\
\hline$\%$ Fine Sand ${ }^{c}$ & 44.12 & 45.20 & 36.17 \\
\hline \% Fines (Silt \& Clay) ${ }^{\mathrm{c}}$ & 13.17 & 23.76 & 13.09 \\
\hline Permeability $^{\mathrm{d}}$ & Moderate & Moderate & Moderate \\
\hline Texture $^{\mathrm{d}}$ & Loamy sand & Loamy sand & Loamy fine sand \\
\hline Drainage Class ${ }^{\mathrm{d}}$ & $\begin{array}{l}\text { Moderately well- } \\
\text { drained }\end{array}$ & $\begin{array}{l}\text { Moderately well- } \\
\text { drained }\end{array}$ & $\begin{array}{l}\text { Somewhat poorly- } \\
\text { drained }\end{array}$ \\
\hline $\begin{array}{l}\text { Depth to Seasonal High } \\
{\text { Water Table }(\mathrm{m})^{\mathrm{d}}}\end{array}$ & $1.0-1.8$ & $0.5-0.8$ & $0.2-0.5$ \\
\hline Organic Matter $(\%)^{\mathrm{d}}$ & $0.5-2.0$ & $0.5-2.0$ & $0.5-5.0$ \\
\hline
\end{tabular}

According to the United States Department of Agriculture (USDA), Goldsboro and Norfolk sandy loams are both moderately well-drained, moderately permeable soils that formed from marine deposits (USDA 2005). The Lynchburg fine-sandy loam is similar to the other soils except that it is categorized as "somewhat poorly-drained". This indicates that water may not 
infiltrate the subsurface as quickly in Lynchburg soil as it would Norfolk or Goldsboro soil. A detailed description of typical soil profiles for each series is listed in Appendix III Supplementary Soil Characteristics.

\subsection{Sorption of Ibuprofen onto Coastal Plain Soils}

Empirical sorption data of ibuprofen in the three soils tested during this experiment are listed in Table 5. Results show that, over the range of concentrations tested, equilibrium ibuprofen solid-water distributions in Goldsboro and Norfolk sandy loams are best described by the Freundlich equation (Figure 5). Freundlich isotherms for ibuprofen in Goldsboro and Norfolk soils had n values of 0.81 and 0.90 respectively. Calculated $\mathrm{K}_{\mathrm{d}}$ and $\mathrm{K}$ values were higher in Goldsboro soils, which also had the greatest $f_{o c}$. There was no significant relationship between the concentration of ibuprofen in the aqueous and the solid phase for the Lynchburg soil isotherm (Figure 6), precluding the calculation of Freundlich sorption parameters for that soil. Calculated $\log \mathrm{K}_{\mathrm{oc}}$ values for all three soils agreed with those from other batch sorption experiments that utilized soils with similar $f_{o c}$ (Table 6). The calculated $\log \mathrm{K}_{\mathrm{oc}}$ values for ibuprofen in all three soils were lower than values derived from the correlation equations proposed by Karickhoff et al. (1979) (Equation 4) by over an order of magnitude.

\begin{tabular}{|c|c|c|c|c|c|c|}
\hline Soil & $\begin{array}{c}\mathbf{K}_{\mathbf{d}} \\
\mathbf{L ~ k g}^{-1}\end{array}$ & $\begin{array}{c}\log K_{o c} \\
\mathrm{~L} \mathrm{~kg}^{-1}\end{array}$ & $\begin{array}{c}\mathrm{K} \\
\mathrm{L} \mathrm{kg}^{-1} \\
\end{array}$ & $\mathbf{n}$ & $\mathbf{r}^{2}$ & $\mathbf{N}$ \\
\hline Goldsboro & $1.26( \pm 0.39)$ & $2.19( \pm 0.12)$ & 3.84 & 0.81 & 0.96 & 4 \\
\hline Norfolk & $0.66( \pm 0.24)$ & $2.21( \pm 0.22)$ & 1.52 & 0.90 & 0.99 & 4 \\
\hline Lynchburg & $0.63( \pm 0.62)$ & $2.29( \pm 0.41)$ & - & - & - & 6 \\
\hline
\end{tabular}



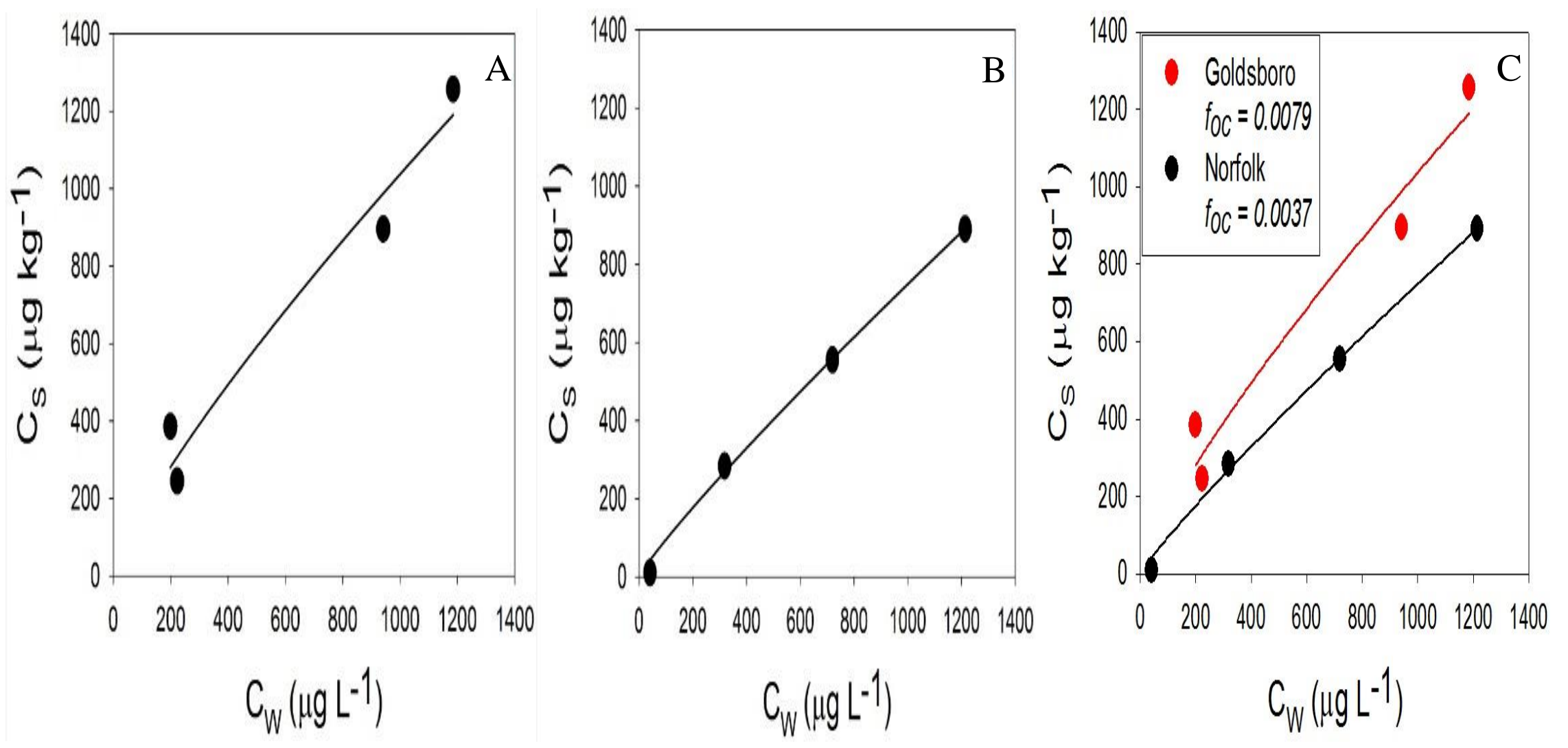

Fig. 5. Freundlich sorption isotherms of ibuprofen in A) Goldsboro sandy loam B) Norfolk sandy loam and C) Goldsboro and Norfolk sandy loam 


\subsection{Discussion}

\subsection{Sorption Isotherms}

Ibuprofen $\mathrm{K}_{\mathrm{d}}$ values in Norfolk and Goldsboro soils $\left(0.66-1.26 \mathrm{~L} \mathrm{~kg}^{-1}\right)$ were similar to findings from Scheytt et al. (2005), who reported $\mathrm{K}_{\mathrm{d}}$ values of $0.18-1.69 \mathrm{~L} \mathrm{~kg}^{-1}$ for ibuprofen in soil with $f_{o c}=0.0013 . \mathrm{K}_{\mathrm{d}}$ values obtained for ibuprofen in Norfolk and Goldsboro soil were used to create sorption isotherms that were best fit by the Freundlich equation. The largest Freundlich adsorption constant $(\mathrm{K})$ obtained in this study was associated with the soil containing the greatest $f_{o c}$, which is consistent with findings from Vulava et al. (2016), Xu et al. (2009), and Yamamoto et al. (2009) (Table 6). Values of n obtained from Freundlich isotherms for Norfolk and Goldsboro soils suggest that as the concentration of ibuprofen in the aqueous phase increased, the sorption affinity for soil remained the same. This implies that at the concentrations tested, ibuprofen did not occupy all available surface sorption sites on Norfolk and Goldsboro soils. However, because calculated $n$ values were $<1$, it is expected that as $C_{w}$ increases, $C_{s}$ will begin to remain constant, implying no further ibuprofen sorption to soil.

Sorption data for ibuprofen in Lynchburg soil showed low correlation between the concentration of ibuprofen in the aqueous versus solid phase (Figure 6). This is likely due to Lynchburg soil properties such as low $f_{o c}$, and high sand content, which provide less compatible sorption sites relative to the other two soils. It is also worth noting that Lynchburg batch treatments had an average aqueous $\mathrm{pH}$ of $6.59 \pm 0.29$ compared to $5.43 \pm 0.07$ and $5.36 \pm 0.04$ for Goldsboro and Norfolk batch treatments, respectively. This was likely due to Lynchburg having a higher soil pH (5.4) than Goldsboro (5.0) and Norfolk (5.2) soils. Behera et al. (2012) found that ibuprofen partitioning to soils in batch studies was inversely correlated with the aqueous $\mathrm{pH}$. 
Ibuprofen is a carboxylic acid with a pKa of 4.9 (Sangster 1989). At pH > pKa, over 50\% of aqueous-phase ibuprofen is expected to be deprotonated (Behera et al., 2012). According to Schwarzenbach et al. (1993), the fraction of a compound present in a liquid as its un-dissociated (neutral) form can be estimated by:

$$
\alpha_{\mathrm{a}}=1 / 1+10^{\wedge}(\mathrm{pH}-\mathrm{pKa})
$$

where $\alpha_{\mathrm{a}}$ is the fraction or percentage of a dissolved compound in its non-dissociated form.

Using Equation 4, the estimated percentage of ibuprofen in the aqueous phases of Goldsboro, Norfolk, and Lynchburg batch treatments, as its non-dissociated form was $24 \%$, $24 \%$, and $2 \%$, respectively. This suggest that $98 \%$ of ibuprofen molecules in the liquid phase of Lynchburg treatments were anions, which are more likely to remain dissolved in the liquid phase. This also may have caused the dissociated form of ibuprofen to be repelled from potential sorption sites, resulting in highly variable empirical $\mathrm{K}_{\mathrm{d}}$ values for ibuprofen as observed in the Lynchburg soil. 


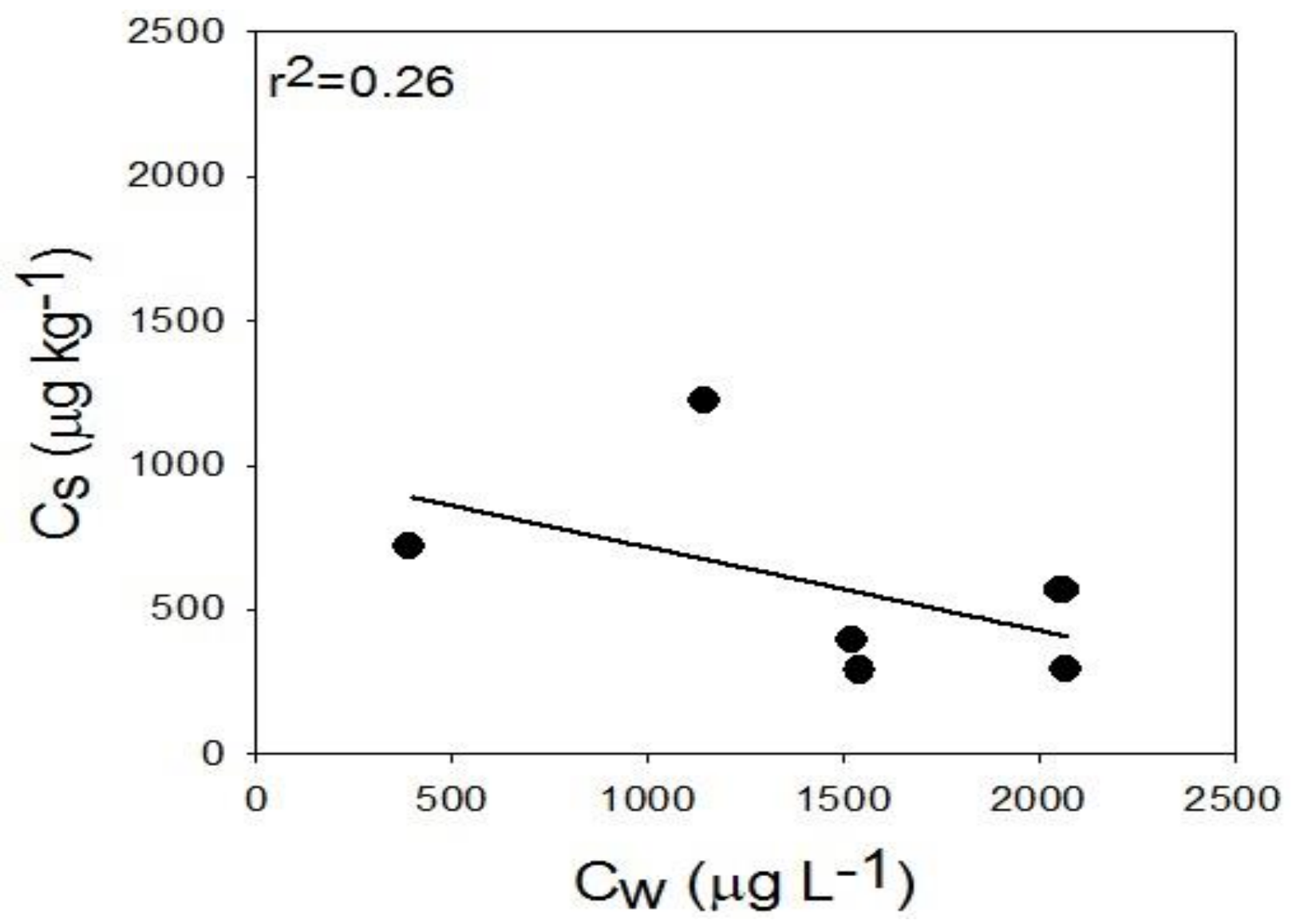

Fig. 6. Sorption isotherm for ibuprofen in Lynchburg finesandy loam.

\subsection{Soil Properties Controlling the Mobility of Ibuprofen in Coastal Plain Soils}

The molecular forces responsible for the partitioning of organic compounds between water and $n$-octanol are also responsible for the partitioning of organic compounds between an aqueous phase and natural organic matter (Karickhoff et al., 1979). The ratio of a compounds concentration between $n$-octanol and an aqueous phase, at equilibrium, is known as its octanolwater partitioning coefficient $\left(\mathrm{K}_{\mathrm{ow}}\right)$, and is used extensively as a proxy for the environmental fate of organic contaminants (Hansch et al., 1977). Numerous correlation equations have been developed in order to estimate a compound's $\log \mathrm{K}_{\mathrm{oc}}$ value from its experimental $\mathrm{K}_{\mathrm{ow}}$ (Schwarzenbach \& Westall 1981; Karickhoff et al., 1979; Kenaga \& Goring 1980; Gerstl 1990; 
Baker et al., 1997). Karickhoff et al. (1979) derived the following linear relationship between the $\log \mathrm{K}_{\mathrm{oc}}$ and $\log \mathrm{K}_{\mathrm{ow}}$ of several non-ionic chemicals such as pyrene and methoxychlor:

$\log \mathrm{K}_{\mathrm{oc}}=1.00 \times \log \mathrm{K}_{\mathrm{ow}}-0.21$

(Equation 5)

Ibuprofen has been shown to have an experimentally determined $\log \mathrm{K}_{\mathrm{ow}}$ value of 3.97 (Avdeef et al., 1998). Using Equation 5, at neutral pH, its theoretical log $\mathrm{K}_{\mathrm{oc}}$ value should equal 3.76 $\mathrm{L} \mathrm{kg}^{-1}$. This suggests that at equilibrium, $\sim 5000$ parts ibuprofen sorbs to soils compared to $\sim 1$ part being dissolved in solution. That value is over an order of magnitude higher than any log $\mathrm{K}_{\mathrm{oc}}$ values determined in this study. Other batch studies analyzing ibuprofen sorption to soils/sediment also determined lower $\log \mathrm{K}_{\mathrm{oc}}$ values than predicted by Karickhoff's two phase equation for non-ionic chemicals (Figure 7). This suggest that in the natural environment, where groundwater $\mathrm{pH}$ is typically > 5 (Becking et al., 1960), the equation given by Karickhoff et al. (1979) may overestimate ibuprofen sorption to soils with low $f_{o c}$. 


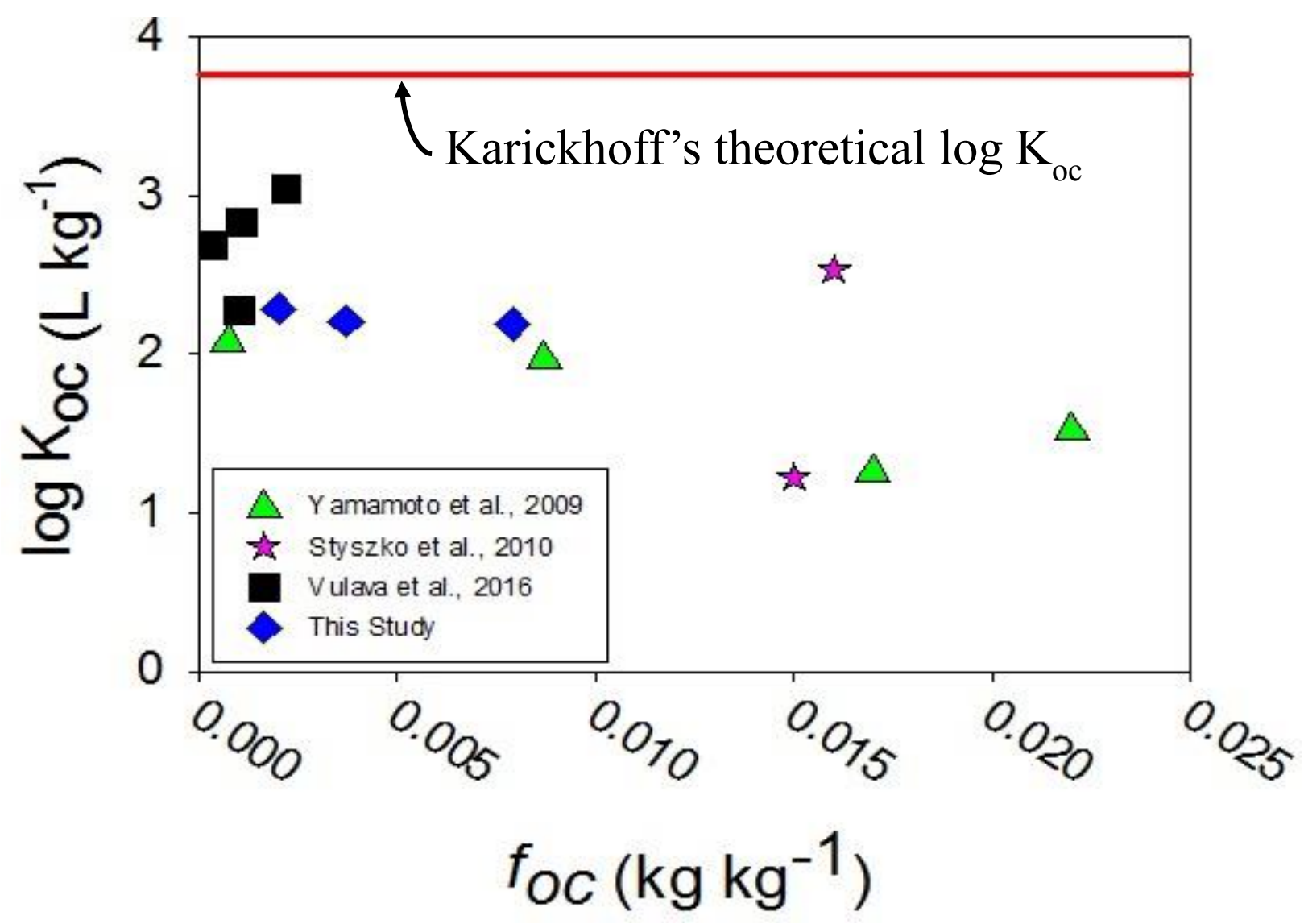

Fig. 7. Relationship between ibuprofen's $\log \mathrm{K}_{\mathrm{oc}}$ and $f_{o c}$. Red line represents ibuprofen's $\log \mathrm{K}_{\mathrm{oc}}$ based on equation derived by Karickhoff (1979). Data suggest that Karickhoff's equation may overestimate ibuprofen partitioning to organic material.

The results of this study suggest that ibuprofen has a higher sorption affinity for soils with greater $f_{o c}$. This is consistent with other studies which also demonstrate a positive relationship between ibuprofen's $\mathrm{K}_{\mathrm{d}}$ and the $f_{o c}$ in soil (Figure 8). It is also important to note that Yamamoto et al. (2009) conducted batch experiments in which the aqueous $\mathrm{pH}$ was greater than ibuprofen's pKa, while Scheytt et al. (2005), Styszko et al. (2010), and Vulava et al. (2016) used batch treatments in which the aqueous $\mathrm{pH}$ was less than ibuprofen's $\mathrm{pKa}$. In the latter mentioned experiments, ibuprofen existed primarily as its non-dissociated form because $\mathrm{pH}<\mathrm{pKa}$, likely 
resulting in higher partition coefficients than those observed by Yamamoto et al. (2009), who used soils with similar $f_{o c}$.

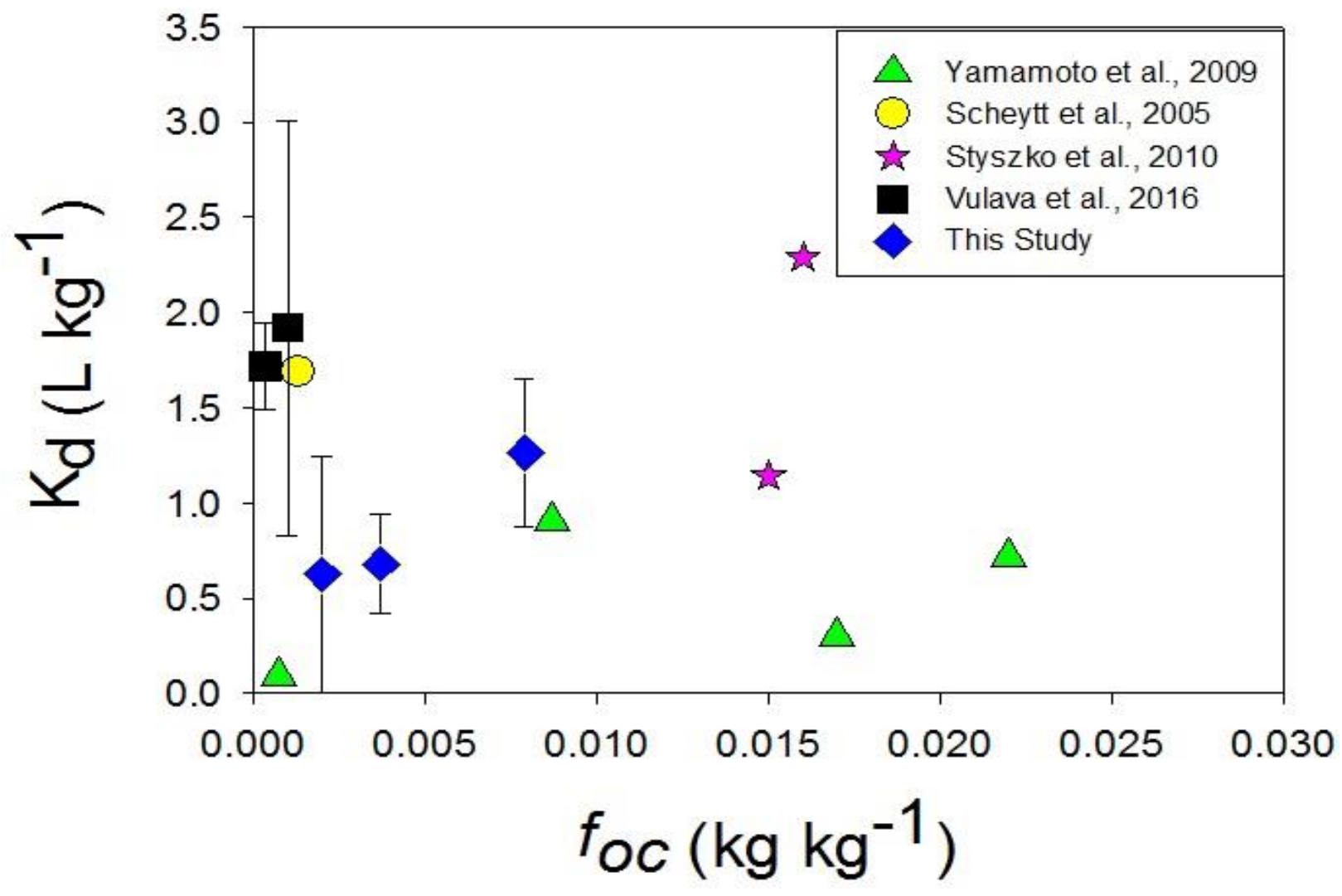

Fig. 8. Relationship between $f_{o c}$ and $\mathrm{K}_{\mathrm{d}}$. Standard error values were not available for certain data.

\subsection{Implications for Ibuprofen Mobility in Contrasting Environments}

Properties other than SOM that have been shown to influence partitioning of organic contaminants in soil-water matrices include soil texture and groundwater chemistry. For example, clay particles are characteristic of negatively charged surface sites that may electrostatically attract cations and/or repel anions (Xu et al., 2009). On the other hand sandy soils typically possess little charge and do not facilitate the presence or formation of SOM, making them poor sorption sites for hydrophobic organic contaminants (Scheytt et al., 2005). 
The aqueous $\mathrm{pH}$ of groundwater and/or surface water can also influence the partitioning of organic contaminants in the environment (Cho et al., 2011). When solution $\mathrm{pH}$ is greater than a compounds $\mathrm{pKa}$, the molecule exist predominantly in its dissociated form, and in its undissociated form when $\mathrm{pH}$ is below the $\mathrm{pKa}$ (Behera et al., 2012). Dissociated compounds are less likely to partition to SOM, increasing their potential mobility in sandy, mineral-rich soils. Table 6 displays ibuprofen sorption parameters from multiple studies that have used soils with various physicochemical properties. Based on this table, it is apparent that many weak carboxylic acids such as ibuprofen $(\mathrm{pKa}<5)$ may exist as their dissociated moieties in the natural environment where $\mathrm{pH}$ is generally $>5$ (Becking et al., 1960).

Due to ibuprofen's low pKa of 4.9, and minimal temporal variability in $\mathrm{pH}$ of Coastal Plain groundwater, it is unlikely that ibuprofen sorption is altered by seasonal groundwater $\mathrm{pH}$ differences on a regional scale (Tesoriero et al., 2004; Sangster 1989). However when groundwater comes into contact with highly acidic minerals such as sulfides, the aqueous $\mathrm{pH}$ may become lower than ibuprofen's pKa, enhancing its affinity for solids (Deutsch \& Siegel 1997). It is also important to note that Geudidi et al. (2013) found that ibuprofen's affinity for an activated carbon material increased with increasing aqueous temperature. In ground and surface waters, an increase in temperature also typically results in an increase in microbial activity, potentially increasing the biodegradation of ibuprofen in the environment (Tixier et al., 2003). These findings suggest that ibuprofen may be removed from ground and surface water at higher rates during warmer months.

Katsoyiannis \& Samara (2007) found a negative correlation between the concentration of DOC and $\mathrm{K}_{\mathrm{d}}$ of organic pollutants in wastewater, implying that DOC may decrease the affinity of organic contaminants for soils and sediments. This was likely due to organic contaminants 
sorbing to hydrophobic surface sites on DOC, effectively eliminating their potential to sorb to soil. Thus, DOC may facilitate the transport of dissolved organic contaminants by decreasing their interaction with solid phases (Warren et al., 2003). For the current study, preliminary experiments determined that the DOC in aqueous phases of Goldsboro, Lynchburg, and Norfolk batch treatments were $8.86 \pm 0.23 \mathrm{mg} \mathrm{L}^{-1}, 9.85 \pm 0.06 \mathrm{mg} \mathrm{L}^{-1}$, and $10.59 \pm 0.15 \mathrm{mg} \mathrm{L}^{-1}$, respectively (Appendix IV. Supplementary Batch Treatment Data). However, Del Rosario et al. (2014) found that DOC in Coastal Plain groundwater located downgradient from septic systems ranged from $\sim 17-36 \mathrm{mg} \mathrm{L}^{-1}$. Thus, concentrations of ibuprofen in the liquid phase of batch treatments from the current study are likely lower than those that would be observed in the natural environment and presumably did not act as a third phase leading to substantial ibuprofenDOC association.

Hydraulic characteristics of soil, such as hydraulic conductivity and effective porosity, determine the rate at which groundwater and its constituents migrate through the subsurface (Heath 1983). Hydraulic conductivity quantitatively describes the water-transmitting characteristics of a material as the volume of water that will move in a unit of time, under a unit hydraulic gradient through a unit area (Heath 1983). Effective porosity is the volume of water that will drain from a soil under the influence of gravity. Clay has smaller grain sizes than sand, resulting in more pore openings (higher porosity). However, the pores are poorly connected and water in these pores does not drain well under gravity. Thus, clay soils typically have low effective porosity and vice versa for sandy soils (Heath 1983). Also, Equation 6 demonstrates that groundwater velocity is directly related to the hydraulic gradient of the water table: $\mathrm{V}=\mathrm{K} / \mathrm{n}_{\mathrm{e}}(\mathrm{dh} / \mathrm{dl})$ (Equation 6) 
where $\mathrm{K}$ is the hydraulic conductivity in $\mathrm{m} \mathrm{d}^{-1}, \mathrm{n}_{\mathrm{e}}$ is the effective porosity and is dimensionless, and $\mathrm{dh} / \mathrm{dl}$ is the hydraulic gradient of groundwater and is also dimensionless.

Humphrey (2009) calculated an average groundwater hydraulic gradient of 0.009 , from multiple piezometers installed in a surficial aquifer located in North Carolina's Outer Coastal Plain. Del Rosario et al. (2014) calculated an average groundwater hydraulic gradient of 0.060, from multiple piezometers installed in a surficial aquifer located in North Carolina's Inner Coastal Plain. Using Equation 6, and assuming that the effective porosity of soil is 0.3 and the hydraulic conductivity $0.2 \mathrm{~m} \mathrm{~d}^{-1}$ (Humphrey 2009 \& Del Rosario et al. 2014, reported similar hydraulic characteristics in North Carolina's Inner and Outer Coastal Plain, respectively), it would take a wastewater plume approximately 375 days to reach a stream located $15 \mathrm{~m}$ away under the hydraulic gradient determined for the Inner Coastal Plain, whereas in the Outer Coastal Plain it would take approximately 2500 days. This indicates that regions such as North Carolina's Inner Coastal Plain may be at greater risk of PPCP transport, opposed to regions with minimal topographic relief, such as North Carolina’s Outer Coastal Plain.

\subsection{Overall Implications}

The mass fraction of organic carbon in Norfolk and Goldsboro soils had a significant influence on the partitioning of ibuprofen from the aqueous to solid phase. Goldsboro loamy sand had the highest concentration of organic carbon $\left(0.0079 \mathrm{~kg} \mathrm{~kg}^{-1}\right)$ followed by Norfolk loamy sand $\left(0.0037 \mathrm{~kg} \mathrm{~kg}^{-1}\right)$ and Lynchburg fine-loamy sand $\left(0.0020 \mathrm{~kg} \mathrm{~kg}^{-1}\right) . \mathrm{K}$ values derived from the Freundlich equation reflect ibuprofen's affinity for the tested soils. In this study, the highest $\mathrm{K}$ value for ibuprofen was associated with the Goldsboro soil (3.84 $\left.\mathrm{L} \mathrm{kg}^{-1}\right)$. The ibuprofen $\mathrm{K}$ value derived from the Norfolk sorption isotherm was $1.52 \mathrm{~kg} \mathrm{~L}^{-1}$. Due to the shape of the isotherm, no K value was determined for ibuprofen in Lynchburg soil. However ibuprofen 
did have lower $\mathrm{K}_{\mathrm{d}}$ values in Lynchburg soils $(0.63 \pm 0.62)$ compared to Goldsboro and Norfolk soils (1.26 \pm 0.39 and $0.66 \pm 0.24$, respectively). Thus, the sorption affinity of ibuprofen for the three soils is as follows:

\section{Lynchburg $<$ Norfolk $<$ Goldsboro}

Correlation equations utilizing a suite of hydrophobic organic compounds affinity for the organic solvent, $n$-octanol, are often used to predict the partitioning of organic contaminants to SOM. However, this study and others indicate that values obtained from correlation equations may overestimate partitioning of ibuprofen in soils with low SOM, such as those found in North Carolina's Inner Coastal Plain. This is likely due to ibuprofen deprotonating when aqueous $\mathrm{pH}$ is above its pKa of 4.9 (Sangster 1989; Behera et al., 2012). The result is an increase in ibuprofen's solubility and polarity, making interactions with SOM less favorable. The $\mathrm{pH}$ of the surficial aquifer in North Carolina's Coastal Plain is typically > 4.9 (Tesoriero et al., 2004). In such environments, ibuprofen is expected to exist primarily in its anionic state, enhancing its mobility.

Diminished attenuation of contaminants in soil beneath OWTS is also affected by improper installation and maintenance. For example, Del Rosario et al. (2014) found that OWTS were least effective in removing PPCPs from effluent when there was a vertical separation distance of less than $10 \mathrm{~cm}$ between the bottom of the drain field trench and the top of the water table. This is due to inadequate wastewater residence time in the vadose zone, where much of the chemical and physical transformation of contaminants occurs (US EPA 2002). The North Carolina Department of Environment, Health, and Natural Resources (NC DEHNR), states that OWTS must have at least a $30 \mathrm{~cm}$ vertical separation distance between the trench bottom and the seasonal high water table (NC DEHNR 1996). NC DEHNR also recommends a $15 \mathrm{~m}$ horizontal separation distance from OWTS to private wells and surface waters (NC DEHNR 1996). 
However, Del Rosario et al. (2014) detected ibuprofen and DEET in an Inner Coastal Plain stream located $52 \mathrm{~m}$ away from an OWTS underlain by sandy permeable soils low in SOM.

The results from this study and others suggest that maximum input of ibuprofen from OWTS and biosolids to ground and surface waters, are more likely in regions with moderate topography, seasonally high water tables, and sandy, permeable soils low in organic material, such as North Carolina's Inner Coastal Plain. Input of PPCPs to the surrounding environment can be highly variable, both spatially and temporally, making best management practices for the distribution of anthropogenic waste in the natural environment challenging. However, there are certain site-specific measurements that can be implemented in order to reduce the transport of PPCPs to ground and surface waters. For example, Del Rosario et al. (2014) did not detect PPCPs in groundwater downgradient from OWTS when the vertical separation distance between the bottom of the drain field trench and water table was $>60 \mathrm{~cm}$. This suggest that $\geq 60 \mathrm{~cm}$ of vadose zone beneath drain field trenches may be necessary for the complete removal of PPCPs in sandy Coastal Plain soils with low SOM. Del Rosario et al. (2014) also detected PPCPs in a stream located $52 \mathrm{~m}$ away from an OWTS, suggesting that the current recommended setback distance of $15 \mathrm{~m}$ may be inadequate in Coastal Plain regions.

Greater topographic relief generally results in an increased hydraulic gradient of the water table, which is directly related to groundwater velocity and contaminant transport (Heath 1983). Greater topographic relief also increases the potential for surface runoff and subsequent transport of organic contaminants to surface waters. Thus, when designating sites for OWTS or when applying biosolids to agricultural land, it is advisable to do so in areas of minimal topographic relief. If this is not feasible, installation of OWTS and/or application of biosolids should not be conducted directly uphill from surface waters or supply wells (Heath 1983). 
Furthermore, this study suggests that in certain Coastal Plain regions, areas that possess abundant SOM, such as riparian buffer zones and permeable reactive barriers, may promote sequestration of PPCPS such as ibuprofen, effectively enhancing the sustainability of adjacent water bodies.

The detection of PPCPs in environmental matrices, such as soil and water, at trace concentrations has only been possible since the 1990s due to advances in analytical technology (Daughton \& Ternes 1999). In the United States, ibuprofen manufacturing and distribution began in 1974 (Rainsford 1999). Therefore, it is possible that ibuprofen and its metabolites, as well as other organic contaminants, may be present in deeper, confined aquifers that have groundwater residence times on the order of decades or greater. This is important because groundwater from confined aquifers is frequently used for anthropogenic purposes such as agriculture and drinking water. This also implies that organic contaminants have the potential to re-enter the biosphere many years following their intended use.

The partitioning of organic contaminants between aqueous and solid phases is in part due to the compounds molecular structure. For example, compounds that have similar functional groups (carboxy, hydroxy, carbonyl, etc.) typically have similar partition coefficients (Bäuerlein et al., 2012). This can be very useful when assessing contaminant transport, considering the vast array of chemicals that are continually released into the environment on a daily basis. Thus, ibuprofen partitioning behavior analyzed in this and other experiments may be used to make inferences on the mobility of structurally similar compounds in the natural environment. 


\begin{tabular}{|c|c|c|c|c|c|c|c|}
\hline $\begin{array}{c}\text { Soil/Sediment } \\
\text { Texture }\end{array}$ & $\begin{array}{l}\text { Soil } \\
\text { pH }\end{array}$ & $\begin{array}{c}\text { OM } \\
\%\end{array}$ & $\begin{array}{c}\text { Foc } \\
\left(\mathrm{kg} \mathrm{kg}^{-1}\right)\end{array}$ & $\begin{array}{c}\text { CEC } \\
\left(\mathrm{me} \mathbf{1 0 0 ~}^{-1}\right)\end{array}$ & $\begin{array}{c}\mathbf{K}_{\mathbf{d}} \\
\left(\mathbf{L ~ k g}^{-1}\right)\end{array}$ & $\begin{array}{l}\log K_{o c} \\
\left(\mathrm{~L} \mathrm{~kg}^{-1}\right)\end{array}$ & Reference \\
\hline sandy loam & 7.9 & 2.91 & & 28.7 & 0.32 & 1.28 & 1 \\
\hline sandy loam & 8.5 & 4.03 & & 39.2 & 0.29 & 1.1 & 1 \\
\hline clay loam & 8.1 & 3.97 & & 29.7 & 0.35 & 1.18 & 1 \\
\hline loam & 8.7 & 0.67 & & 30.7 & 0.04 & 1.04 & 1 \\
\hline loamy sand & $\begin{array}{c}7.5 \\
4\end{array}$ & 0.58 & & & $0.56( \pm 0.22)$ & $2.11( \pm 0.20)$ & 2 \\
\hline sandy loam & $\begin{array}{c}7.0 \\
6\end{array}$ & 1.93 & & & $0.56( \pm 0.17)$ & $2.01( \pm 0.14)$ & 2 \\
\hline silt clay & $\begin{array}{c}7.4 \\
8\end{array}$ & 2.46 & & & $1.24( \pm 0.26)$ & $1.94( \pm 0.09)$ & 2 \\
\hline silt loam & $\begin{array}{c}7.1 \\
4\end{array}$ & 5.45 & & & $3.71( \pm 0.46)$ & $2.07( \pm 0.05)$ & 2 \\
\hline river sediment & 6.7 & & $8.00 \mathrm{E}-04$ & 2 & 0.093 & 2.08 & 3 \\
\hline river sediment & 6.6 & & $8.70 \mathrm{E}-03$ & 11 & 0.91 & 1.97 & 3 \\
\hline river sediment & 5.7 & & $1.70 \mathrm{E}-02$ & 14 & 0.3 & 1.26 & 3 \\
\hline $\begin{array}{l}\text { silt loam } \\
\text { fine sand }\end{array}$ & $\begin{array}{l}6.6 \\
4.8\end{array}$ & & $\begin{array}{l}2.20 \mathrm{E}-02 \\
1.30 \mathrm{E}-03\end{array}$ & $\begin{array}{c}28 \\
4\end{array}$ & $\begin{array}{l}0.72 \\
0.18\end{array}$ & 1.52 & $\begin{array}{l}3 \\
4\end{array}$ \\
\hline silt sediments & 7.7 & & $1.50 \mathrm{E}-02$ & & 1.14 & 1.22 & 5 \\
\hline \multirow[t]{5}{*}{ silt sediments } & 7.6 & & $1.60 \mathrm{E}-02$ & & 2.29 & 2.53 & 5 \\
\hline & & & $3.50 \mathrm{E}-04$ & & $1.72( \pm 0.23)$ & 2.69 & 6 \\
\hline & & & $1.00 \mathrm{E}-03$ & & $1.92( \pm 1.09)$ & 2.28 & 6 \\
\hline & & & $1.09 \mathrm{E}-03$ & & $7.38( \pm 0.57)$ & 2.83 & 6 \\
\hline & & & $2.20 \mathrm{E}-03$ & & $24.4( \pm 0.60)$ & 3.04 & 6 \\
\hline loamy sand & 5 & & $7.90 \mathrm{E}-03$ & 3.3 & $1.26( \pm 0.39)$ & $2.19( \pm 0.12)$ & 7 \\
\hline loamy sand & 5.2 & & $3.70 \mathrm{E}-03$ & 3.5 & $0.66( \pm 0.24)$ & $2.21( \pm 0.22)$ & 7 \\
\hline $\begin{array}{c}\text { loamy-fine } \\
\text { sand }\end{array}$ & 5.4 & & $2.00 \mathrm{E}-03$ & 2.5 & $0.63( \pm 0.62)$ & $2.29( \pm 0.41)$ & 7 \\
\hline \multicolumn{8}{|c|}{$\begin{array}{l}{ }^{1} \text { Estevez et al., } 2014 \\
{ }^{2} \text { Xu et al., 2009 } \\
{ }^{3} \text { Yamamoto et al., } 2009 \\
{ }^{4} \text { Scheytt et al., } 2005 \\
{ }^{5} \text { Styszko et al., 2010 } \\
{ }^{6} \text { Vulava et al., } 2016 \\
{ }^{7} \text { This Study }\end{array}$} \\
\hline
\end{tabular}




\section{References}

Avdeef, A., Box, K. J., Comer, J. E. A., Hibbert, C., \& Tam, K. Y. 1998. Determination of liposomal membrane-water partition coefficients of lonizable drugs. Pharmaceutical Research. 15: 209-215.

Baker, J. R., Mihelcic, J. R., Luehrs, D. C., \& Hickey, J. P. 1997. Evaluation of estimation methods for organic carbon normalized sorption coefficients. Water Environment Research. 69: 136-145.

Barnes, K. K., Kolpin, D. W., Furlong, E. T., Zaugg, S. D., Meyer, M. T., \& Barber, L. B. 2008. A national reconnaissance of pharmaceuticals and other organic wastewater contaminants in the United States-I) Groundwater. Science of the Total Environment. 402: 192-200.

Bäuerlein, P. S., Mansell, J. E., ter Laak, T. L., \& de Voogt, P. 2012. Sorption behavior of charged and neutral polar organic compounds on solid phase extraction materials: which functional group governs sorption? Environmental Science \& Technology. 46: 954-961.

Becking, L. B., Kaplan, I. R., \& Moore, D. 1960. Limits of the natural environment in terms of $\mathrm{pH}$ and oxidation-reduction potentials. The Journal of Geology. 68: 243-284.

Behera, S. K., Oh, S. Y., \& Park, H. S. 2012. Sorptive removal of ibuprofen from water using selected soil minerals and activated carbon. International Journal of Environmental Science and Technology. 9: 85-94.

Bunch, A. R., \& Bernot, M. J. 2011. Distribution of nonprescription pharmaceuticals in central Indiana streams and effects on sediment microbial activity. Ecotoxicology. 20: 97-109.

Bundschuh, M., Hahn, T., Gessner, M. O., \& Schulz, R. 2009. Antibiotics as a chemical stressor affecting an aquatic decomposer-detritivore system. Environmental Toxicology and Chemistry. 28: 197-203.

Chenxi, W., Spongberg, A. L., \& Witter, J. D. 2008. Determination of the persistence of pharmaceuticals in biosolids using liquid-chromatography tandem mass spectrometry. Chemosphere. 73: 511-518.

Chiou, C. T., Peters, L. J., \& Freed, V. H. 1979. A physical concept of soil-water equilibria for nonionic organic compounds. Science. 206: 831-832.

Cho, H. H., Huang, H., \& Schwab, K. 2011. Effects of solution chemistry on the adsorption of ibuprofen and triclosan onto carbon nanotubes. Langmuir. 27: 12960-12967. 
Curiel Yuste, J., Baldocchi, D. D., Gershenson, A., Goldstein, A., Misson, L., \& Wong, S. 2007. Microbial soil respiration and its dependency on carbon inputs, soil temperature and moisture. Global Change Biology, 13: 2018-2035.

Daniels, R. B., Gamble, E. E., \& Cady, J. G. 1970. Some relations among Coastal Plain soils and geomorphic surfaces in North Carolina. Soil Science Society of America Journal. 34: 648-653.

Daniels, R. B., Gamble, E. E., \& Wheeler, W. H. 1978. Age of soil landscapes in the Coastal Plain of North Carolina. Soil Science Society of America Journal. 42: 98-105.

Danielson, N. D., Gallagher, P. A., \& Bao, J. J. 2000. Chemical reagents and derivatization procedures in drug analysis. Encyclopedia of Analytical Chemistry. 7042-7076.

Daughton, C. G., \& Ternes, T. A. 1999. Pharmaceuticals and personal care products in the environment: agents of subtle change? Environmental Health Perspectives. 107: 907-938.

Del Rosario, K. L., Mitra, S., Humphrey, C. P., \& O'Driscoll, M. A. 2014. Detection of pharmaceuticals and other personal care products in groundwater beneath and adjacent to onsite wastewater treatment systems in a coastal plain shallow aquifer. Science of the Total Environment. 487: 216-223.

Dodgen, L. K., Li, J., Wu, X., Lu, Z., \& Gan, J. J. 2014. Transformation and removal pathways of four common PPCP/EDCs in soil. Environmental Pollution. 193: 29-36.

Dougherty, J. A., Swarzenski, P. W., Dinicola, R. S., \& Reinhard, M. 2010. Occurrence of herbicides and pharmaceutical and personal care products in surface water and groundwater around Liberty Bay, Puget Sound, Washington. Journal of Environmental Quality. 39:11731180.

Drillia, P., Stamatelatou, K., \& Lyberatos, G. 2005. Fate and mobility of pharmaceuticals in solid matrices. Chemosphere. 60: 1034-1044.

Duffera, M., White, J. G., \& Weisz, R. 2007. Spatial variability of Southeastern US Coastal Plain soil physical properties: Implications for site-specific management. Geoderma. 137: 327-339.

Ericson, H., Thorsén, G., \& Kumblad, L. 2010. Physiological effects of diclofenac, ibuprofen and propranolol on Baltic Sea blue mussels. Aquatic Toxicology. 99: 223-231.

Estevez, E., Hernandez-Moreno, J. M., Fernandez-Vera, J. R., \& Palacios-Diaz, M. P. 2014. Ibuprofen adsorption in four agricultural volcanic soils. Science of the Total Environment. 468: 406-414.

Foster, S. S. D., \& Chilton, P. J. 2003. Groundwater: the processes and global significance of aquifer degradation. Philosophical Transactions of the Royal Society of London B: Biological Sciences. 358: 1957-1972. 
Gerstl, Z. 1990. Estimation of organic chemical sorption by soils. Journal of Contaminant Hydrology. 6: 357-375.

Guedidi, H., Reinert, L., Lévêque, J. M., Soneda, Y., Bellakhal, N., \& Duclaux, L. 2013. The effects of the surface oxidation of activated carbon, the solution $\mathrm{pH}$ and the temperature on adsorption of ibuprofen. Carbon, 54: 432-443.

Halling-Sørensen, B., Nielsen, S. N., Lanzky, P. F., Ingerslev, F., Lützhøft, H. H., \& Jørgensen, S. E. 1998. Occurrence, fate and effects of pharmaceutical substances in the environment-A review. Chemosphere. 36: 357-393.

Han, S., Choi, K., Kim, J., Ji, K., Kim, S., Ahn, B. \& Giesy, J. P. 2010. Endocrine disruption and consequences of chronic exposure to ibuprofen in Japanese medaka (Oryzias latipes) and freshwater cladocerans Daphnia magna and Moina macrocopa. Aquatic Toxicology. 98: 256264.

Hansch, C., Rockwell, S. D., Jow, P. Y., Leo, A., \& Steller, E. E. 1977. Substituent constants for correlation analysis. Journal of Medicinal Chemistry. 20: 304-306.

Harned, D., McMahon, G., Spruill, T. B., \& Woodside, M. D. 1995. Water-quality assessment of the Albemarle-Pamlico drainage basin, North Carolina and Virginia; characterization of suspended sediment, nutrients, and pesticides (No. 95-191). US Geological Survey; US Geological Survey, Earth Science Information Center, Open-File Reports Section.

Heath, R. C. 1983. Basic ground-water hydrology. US Geological Survey.

Heberer, T. 2002. Occurrence, fate, and removal of pharmaceutical residues in the aquatic environment: a review of recent research data. Toxicology Letters. 131: 5-17.

Hernandez-Ruiz, S., Abrell, L., Wickramasekara, S., Chefetz, B., \& Chorover, J. 2012. Quantifying PPCP interaction with dissolved organic matter in aqueous solution: combined use of fluorescence quenching and tandem mass spectrometry. Water Research. 46: 943-954.

Horton, R. E. 1945. Erosional development of streams and their drainage basins; hydrophysical approach to quantitative morphology. Geological Society of America Bulletin. 56: 275-370.

Humphrey Jr, C. P. 2009. Controls on septic system wastewater treatment and shallow groundwater quality in coastal North Carolina. East Carolina University.

Jones, O. A. H., Voulvoulis, N., \& Lester, J. N. 2004. Potential ecological and human health risks associated with the presence of pharmaceutically active compounds in the aquatic environment. Critical Reviews in Toxicology. 34: 335-350.

Karickhoff, S. W. 1984. Organic pollutant sorption in aquatic systems. Journal of Hydraulic Engineering. 110: 707-735. 
Karickhoff, S. W., Brown, D. S., \& Scott, T. A. 1979. Sorption of hydrophobic pollutants on natural sediments. Water Research. 13: 241-248.

Katsoyiannis, A., \& Samara, C. 2007. The fate of dissolved organic carbon (DOC) in the wastewater treatment process and its importance in the removal of wastewater contaminants. Environmental Science and Pollution Research-International. 14: 284-292.

Keil, A., Wing, S., \& Lowman, A. 2011. Suitability of public records for evaluating health effects of treated sewage sludge in North Carolina. North Carolina Medical Journal. 72: 98-104.

Kenaga, E. E., \& Goring, C. A. I. 1980. Relationship between water solubility, soil sorption, octanol-water partitioning, and concentration of chemicals in biota. Aquatic Toxicology. 707: 78-115.

Kinney, C. A., Furlong, E. T., Zaugg, S. D., Burkhardt, M. R., Werner, S. L., Cahill, J. D., \& Jorgensen, G. R. 2006. Survey of organic wastewater contaminants in biosolids destined for land application. Environmental Science \& Technology. 40: 7207-7215.

Kolpin, D. W., Furlong, E. T., Meyer, M. T., Thurman, E. M., Zaugg, S. D., Barber, L. B., \& Buxton, H. T. 2002. Pharmaceuticals, hormones, and other organic wastewater contaminants in US streams, 1999- 2000: A national reconnaissance. Environmental Science \& Technology. 36: 1202-1211.

Kristensen, D. M., Mazaud-Guittot, S., Gaudriault, P., Lesné, L., Serrano, T., Main, K. M., \& Jégou, B. 2016. Analgesic use prevalence, biomonitoring and endocrine and reproductive effects. Nature Reviews Endocrinology. 12: 381-393.

Larsen, T. A., Lienert, J., Joss, A., \& Siegrist, H. 2004. How to avoid pharmaceuticals in the aquatic environment. Journal of Biotechnology. 113: 295-304.

Maamar, M. B., Lesné, L., Hennig, K., Desdoits-Lethimonier, C., Kilcoyne, K. R., Coiffec, I. \& Antignac, J. P. 2017. Ibuprofen results in alterations of human fetal testis development. Scientific Reports. 7: 44184.

Markewich, H. W., Pavich, M. J., \& Buell, G. R. 1990. Contrasting soils and landscapes of the Piedmont and Coastal Plain, eastern United States. Geomorphology. 3: 417-447.

Markewich, H.W., Pavich, M.J., Mausbach, M.J., Stuckey, B.N., Johnson, R.G. and Gonzalez, Virginia 1986. Soil development and its relation to the ages of morphostratigraphic units in Horry County, South Carolina. U.S. Geological Survey Bulletin. 1589-B: 61.

McClellan, K., \& Halden, R. U. 2010. Pharmaceuticals and personal care products in archived US biosolids from the 2001 EPA national sewage sludge survey. Water Research. 44: 658-668.

Miller, B. J. 1983. Ultisols. Developments in Soil Science. 11: 283-323. 
Mills, R. F. N., Adams, S. S., Cliffe, E. E., Dickinson, W., \& Nicholson, J. S. 1973. The metabolism of ibuprofen. Xenobiotica. 3: 589-598.

National Oceanic \& Atmospheric Administration 2016. Climate Atlas of the United States. Accessed 20 April 2016 from https://www.ncdc.noaa.gov/climateatlas/

North Carolina Department of Environment, Health, and Natural Resources (NC DEHNR). 1996. On-Site Wastewater Management: Guidance Manual. North Carolina Department of Environment, Health, and Natural Resources, Division of Environmental Health, On-Site Wastewater Section, Raleigh, NC.

Richardson, M. L., \& Bowron, J. M. 1985. The fate of pharmaceutical chemicals in the aquatic environment. Journal of Pharmacy and Pharmacology. 37: 1-12.

Sangster, J. 1989. Octanol-water partition coefficients of simple organic compounds. Journal of Physical and Chemical Reference Data. 18: 1111-1229.

Scheytt, T., Mersmann, P., Lindstädt, R., \& Heberer, T. 2005. Determination of sorption coefficients of pharmaceutically active substances carbamazepine, diclofenac, and ibuprofen, in sandy sediments. Chemosphere. 60: 245-253.

Scheytt, T., Mersmann, P., Lindstädt, R., \& Heberer, T. 2005. 1-Octanol/water partition coefficients of 5 pharmaceuticals from human medical care: carbamazepine, clofibric acid, diclofenac, ibuprofen, and propyphenazone. Water, Air, \& Soil Pollution. 165: 3-11.

Scheytt, T. J., Mersmann, P., \& Heberer, T. 2006. Mobility of pharmaceuticals carbamazepine, diclofenac, ibuprofen, and propyphenazone in miscible-displacement experiments. Journal of Contaminant Hydrology. 83: 53-69.

Schwarzenbach, R. P., \& Westall, J. 1981. Transport of non-polar organic pollutants in a river water-groundwater infiltration system: A Systematic Approach. Studies in Environmental Science. 17: 569-574.

Schwarzenbach, R. P., Gschwend, P. M., \& Imboden, D. M. 1993. Organic acids and bases: acidity constant and partitioning behavior. Environmental Organic Chemistry. 245-274.

Sipma, J., Osuna, B., Collado, N., Monclús, H., Ferrero, G., Comas, J., \& Rodriguez-Roda, I. 2010. Comparison of removal of pharmaceuticals in MBR and activated sludge systems. Desalination. 250: 653-659.

Soller, D. R., \& Mills, H. H. 1991. Surficial geology and geomorphology. The geology of the Carolinas. 290-308. 
Spruill, T. B., Eimers, J. L., \& Morey, A. E. 1997. Nitrate-nitrogen concentrations in shallow ground water of the coastal plain of the Albemarle-Pamlico drainage study unit, North Carolina and Virginia. Fact Sheet FS-241-96. Reston, Va. US Geological Survey.

Stein, K., Ramil, M., Fink, G., Sander, M., \& Ternes, T. A. 2008. Analysis and sorption of psychoactive drugs onto sediment. Environmental Science \& Technology. 42: 6415-6423.

Stuckey, J. L. 1965. North Carolina: its geology and mineral resources. Department of Conservation and Development.

Styszko, K., Sosnowska, K., Wojtanowicz, P., Gołaś, J., Gorecki, J., \& Macherzynski, M. 2010. Sorption of ibuprofen on sediments from the Dobczyce (Southern Poland) drinking water reservoir. Archives of Environmental Protection. 36: 81-91.

Sui, Q., Cao, X., Lu, S., Zhao, W., Qiu, Z., \& Yu, G. 2015. Occurrence, sources and fate of pharmaceuticals and personal care products in the groundwater: a review. Emerging Contaminants. 1: 14-24.

Sun, G., McNulty, S. G., Amatya, D. M., Skaggs, R. W., Swift, L. W., Shepard, J. P., \& Riekerk, H. 2002. A comparison of the watershed hydrology of coastal forested wetlands and the mountainous uplands in the Southern US. Journal of Hydrology. 263: 92-104.

Ternes, T., Bonerz, M., \& Schmidt, T. 2001. Determination of neutral pharmaceuticals in wastewater and rivers by liquid chromatography-electrospray tandem mass spectrometry. Journal of Chromatography. 938: 175-185.

Ternes, T. A., Meisenheimer, M., McDowell, D., Sacher, F., Brauch, H. J., Haist-Gulde, B., \& Zulei-Seibert, N. 2002. Removal of pharmaceuticals during drinking water treatment. Environmental Science \& Technology. 36: 3855-3863.

Tesoriero, A. J., Spruill, T. B., \& Eimers, J. L. 2004. Geochemistry of shallow ground water in coastal plain environments in the southeastern United States: implications for aquifer susceptibility. Applied Geochemistry. 19: 1471-1482.

Tixier, C., Singer, H. P., Oellers, S., \& Müller, S. R. 2003. Occurrence and fate of carbamazepine, clofibric acid, diclofenac, ibuprofen, ketoprofen, and naproxen in surface waters. Environmental science \& technology. 37: 1061-1068.

United States Department of Agriculture (USDA) Natural Resources and Conservation Service (NRCS). 2005. GOLDSBORO SERIES. Retrieved from: https://soilseries.sc.egov.usda.gov/OSD_Docs/G/GOLDSBORO.html

United States Department of Agriculture (USDA) Natural Resources and Conservation Service (NRCS) 2005. NORFOLK SERIES. Retrieved from: https://soilseries.sc.egov.usda.gov/OSD_Docs/N/NORFOLK.html 
United States Department of Agriculture (USDA) Natural Resources and Conservation Service (NRCS) 2008. LYNCHBURG SERIES. Retrieved from:

https://soilseries.sc.egov.usda.gov/OSD_Docs/L/LYNCHBURG.html

United States Department of Agriculture (USDA) Natural Resources and Conservation Service (NRCS). 2016. Retrieved from: https://gdg.sc.egov.usda.gov/GDGOrder.aspx?order=QuickState

United States Environmental Protection Agency. 2002. Onsite wastewater treatment systems manual. Report \#EPA/625/R-00/008. Washington, DC: Office of Water and Office of Research and Development.

United States Census Bureau 1999. 1997 National Data Chart for Total Occupied Housing Units.

Vulava, V. M., Cory, W. C., Murphey, V. L., \& Ulmer, C. Z. 2016. Sorption, photodegradation, and chemical transformation of naproxen and ibuprofen in soils and water. Science of the Total Environment. 565: 1063-1070.

Warren, N., Allan, I. J., Carter, J. E., House, W. A., \& Parker, A. 2003. Pesticides and other micro-organic contaminants in freshwater sedimentary environments - a review. Applied Geochemistry. 18: 159-194.

Winner Jr, M. D., \& Coble, R. W. 1996. Hydrogeologic framework of the North Carolina coastal plain. U.S. Geological Survey Professional Paper: 1404-1.

Wu, S. C., \& Gschwend, P. M. 1986. Sorption kinetics of hydrophobic organic compounds to natural sediments and soils. Environmental Science \& Technology. 20: 717-725.

Xia, K., Bhandari, A., Das, K., \& Pillar, G. 2005. Occurrence and fate of pharmaceuticals and personal care products (PPCPs) in biosolids. Journal of Environmental Quality. 34: 91-104.

Xu, J., Wu, L., \& Chang, A. C. 2009. Degradation and adsorption of selected pharmaceuticals and personal care products (PPCPs) in agricultural soils. Chemosphere. 77: 1299-1305.

Yalkowsky, S. H., \& Dannenfelser, R. M. 1992. Aquasol database of aqueous solubility. College of Pharmacy, University of Arizona, Tucson, AZ.

Yamamoto, H., Nakamura, Y., Moriguchi, S., Nakamura, Y., Honda, Y., Tamura, I. \& Sekizawa, J. 2009. Persistence and partitioning of eight selected pharmaceuticals in the aquatic environment: laboratory photolysis, biodegradation, and sorption experiments. Water Research. 43: 351-362.

Yu, Y., Liu, Y., \& Wu, L. 2013. Sorption and degradation of pharmaceuticals and personal care products (PPCPs) in soils. Environmental Science and Pollution Research. 20: 4261-4267. 
Zhu, S., \& Chen, H. 2014. The fate and risk of selected pharmaceutical and personal care products in wastewater treatment plants and a pilot-scale multistage constructed wetland system. Environmental Science and Pollution Research. 21: 1466-1479. 


\section{Appendix I. Supplementary Site Characteristics}

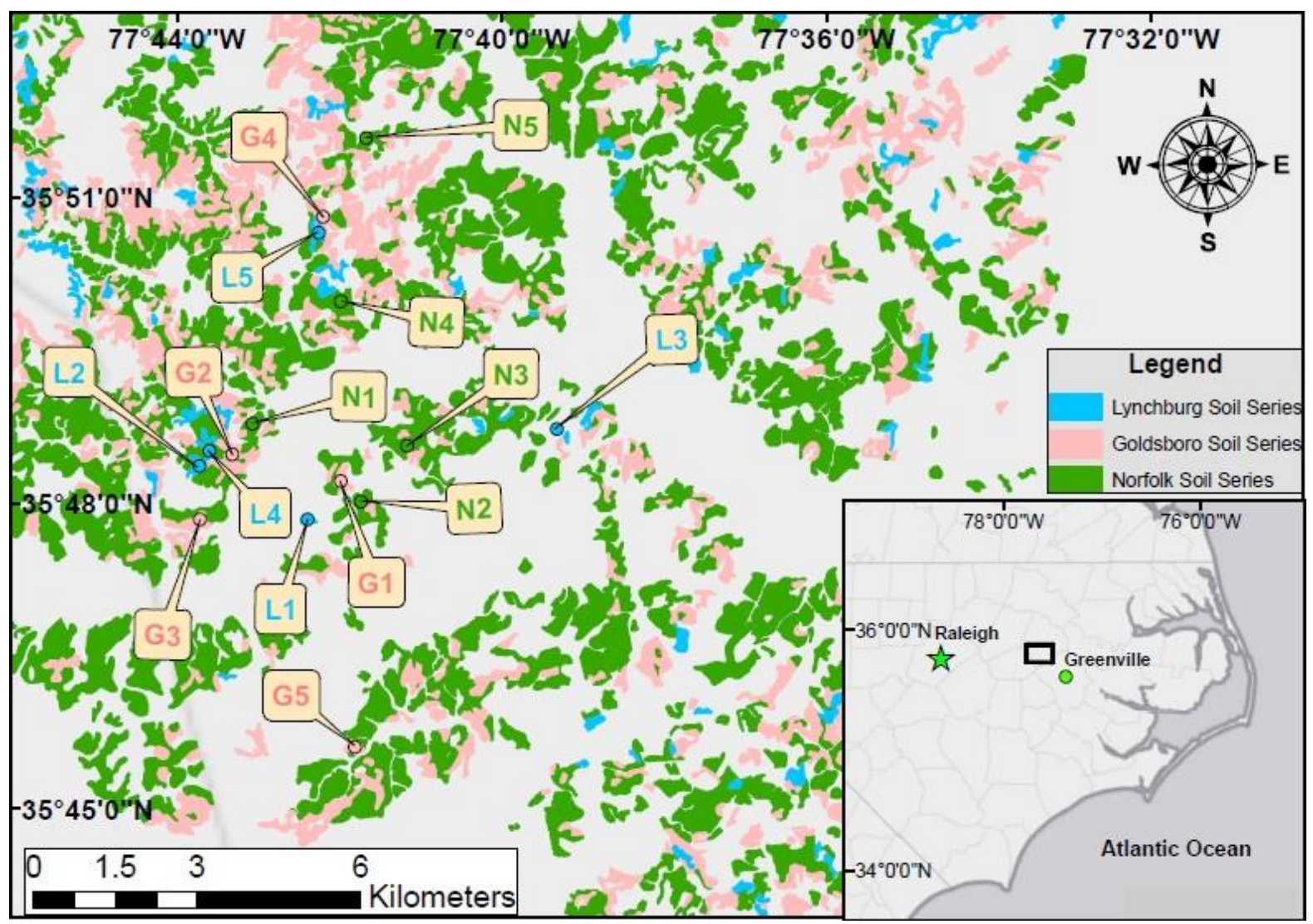

Fig. A1. Layout of sample locations throughout southern Edgecombe County, NC. 


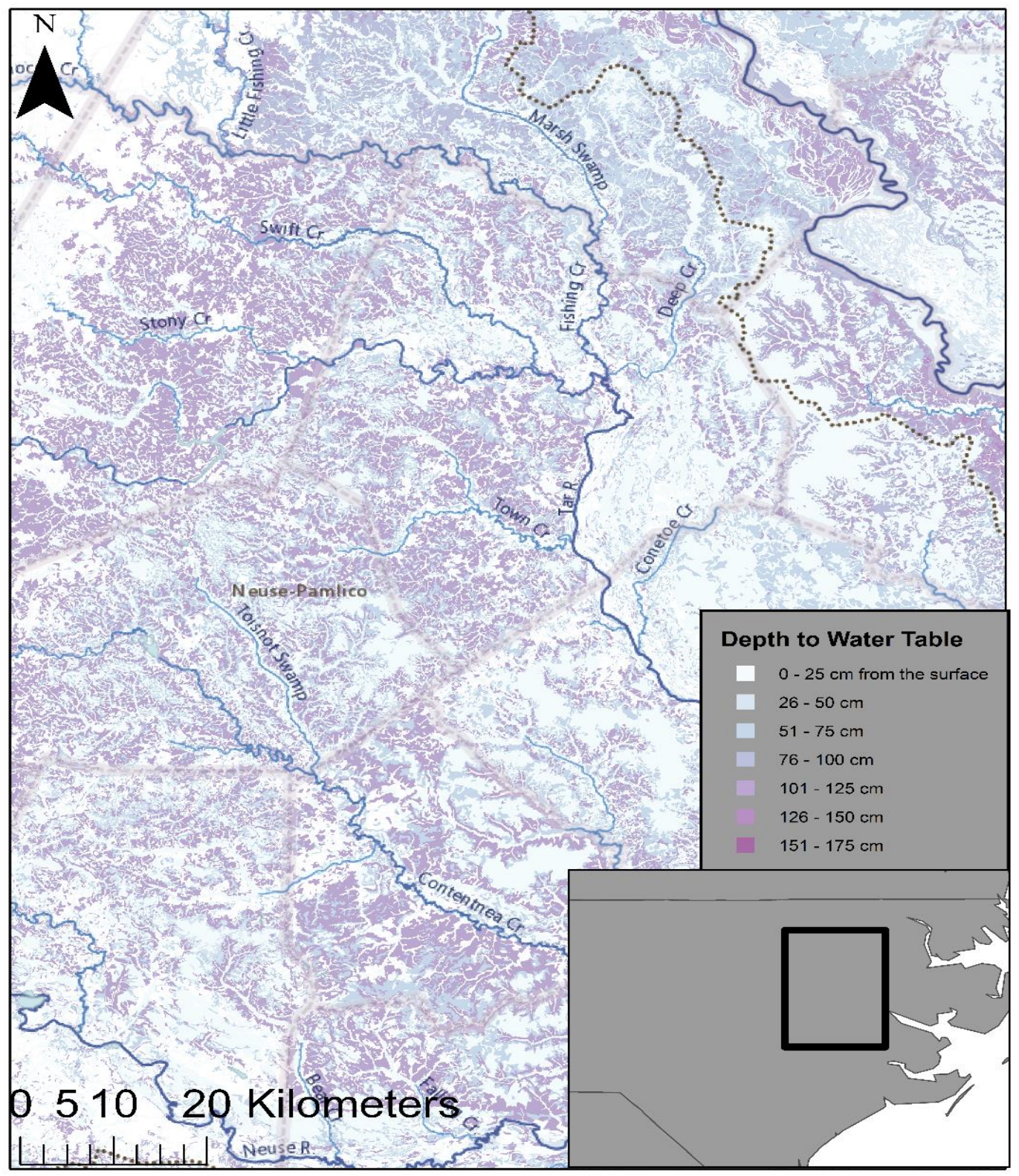

Fig. A2. Image showing depth to water table in North Carolinas Coastal Plain. Map scale is 1:600,000 and resolution is 30 meters. Created using base map data from ArcGIS 10.2. 


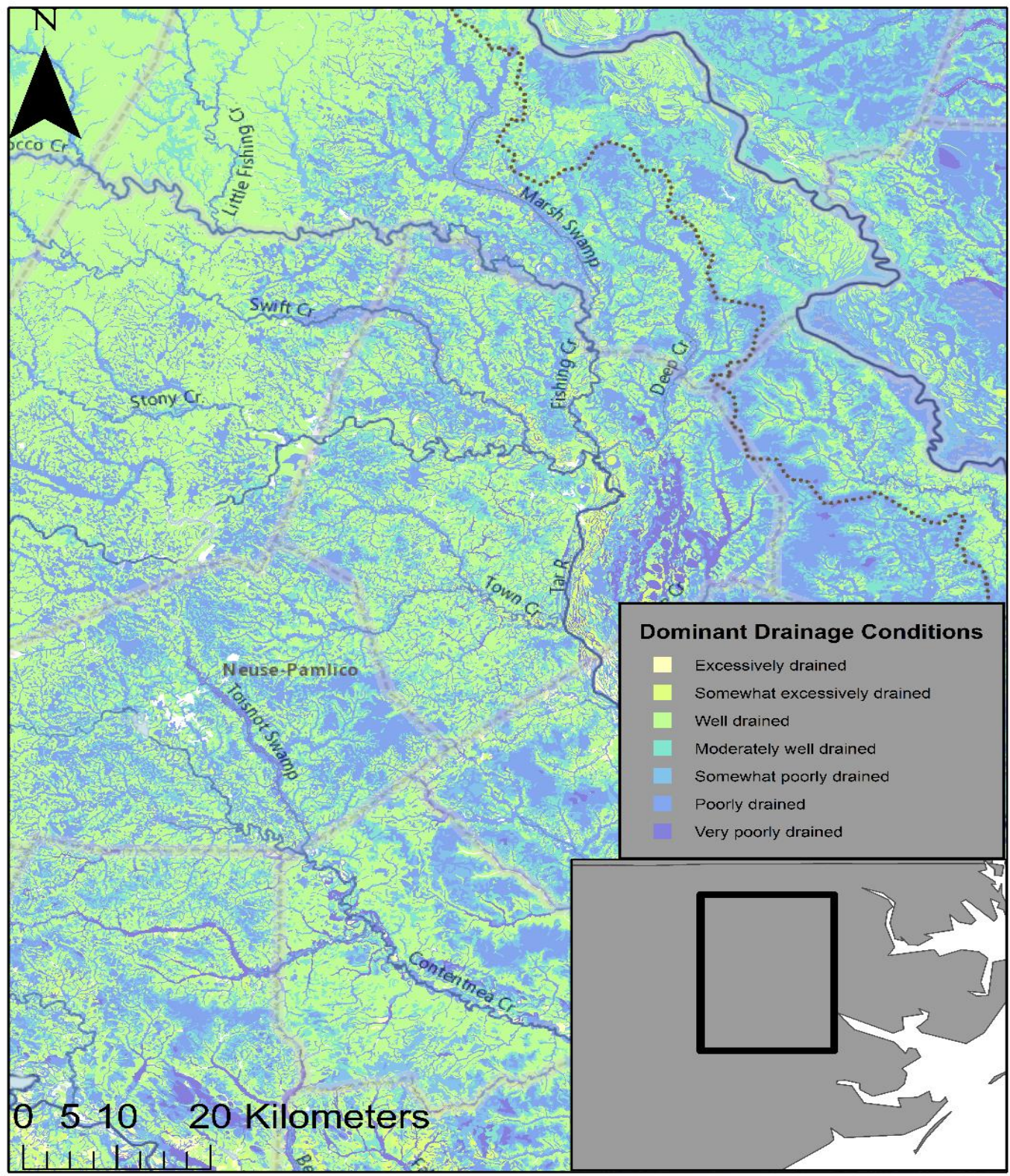

Fig. A3. Image showing drainage characteristics in North Carolinas Coastal Plain. Map scale is 1:600,000 and resolution is 30 meters. Created using base map data from ArcGIS 10.2 


\section{Appendix II. Chromatograms and Mass Spectra of Compounds Tested}

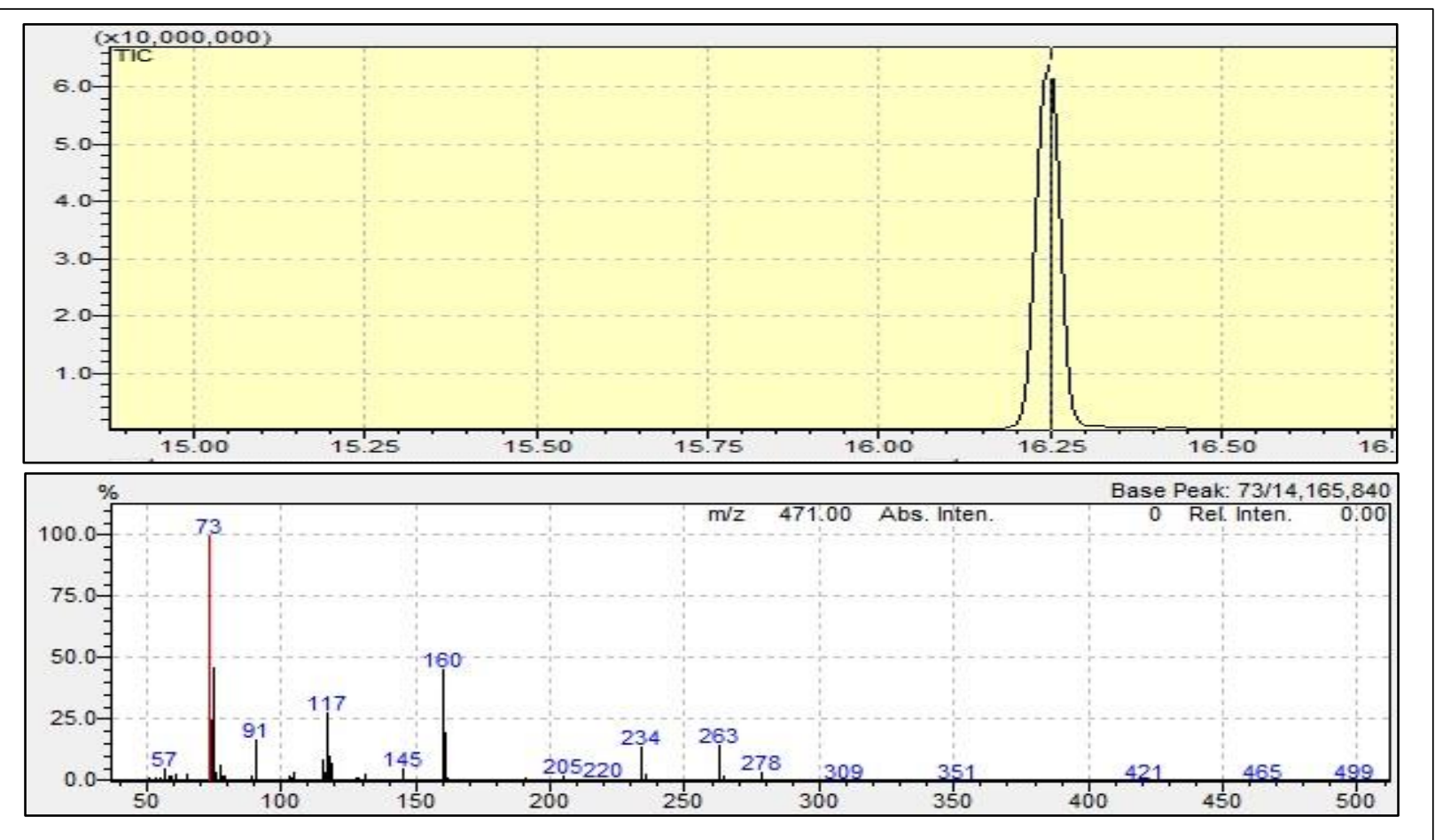

Fig. A4. Ibuprofen chromatogram and mass spectrum.

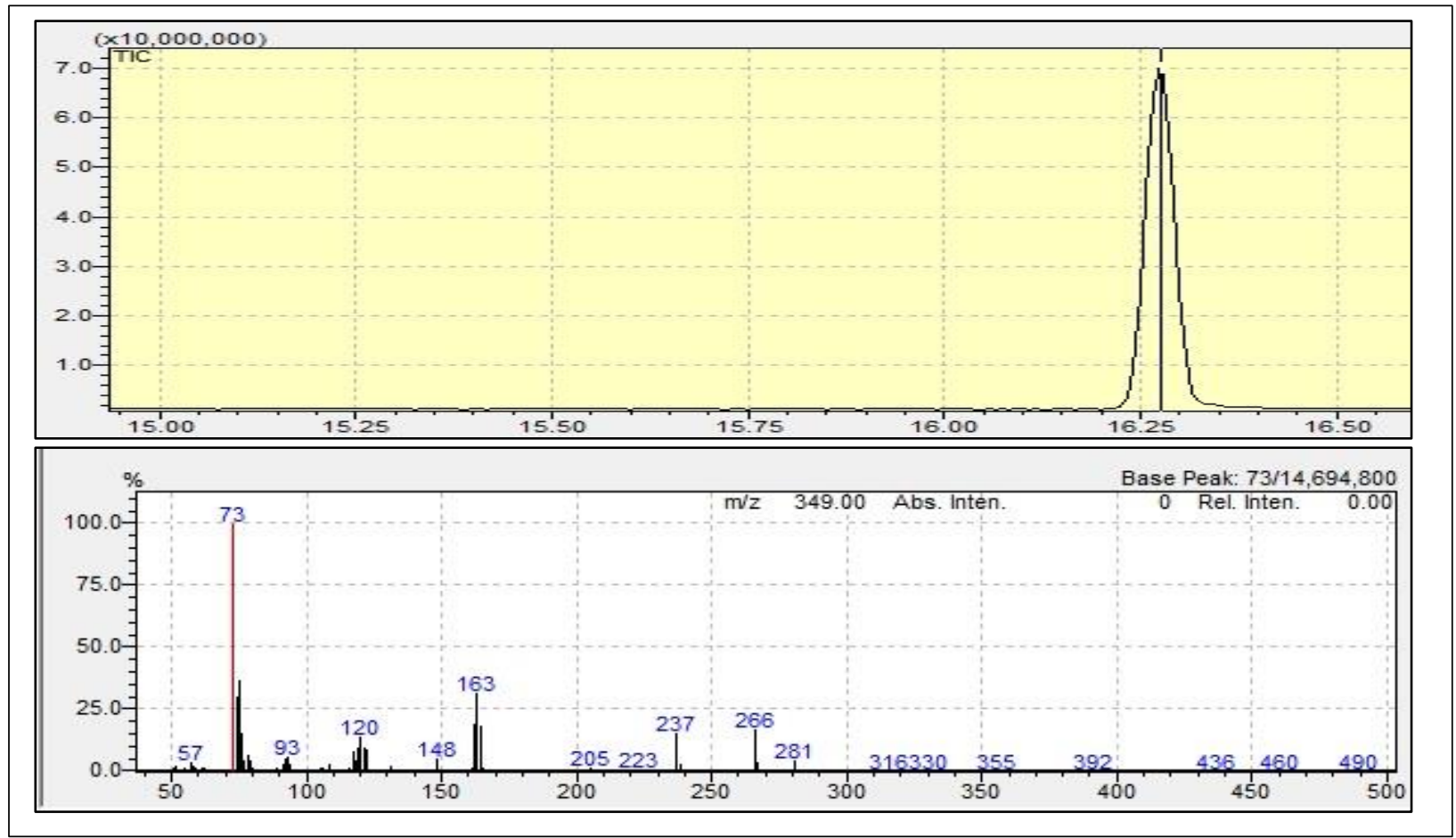

Fig. A5. Ibuprofen- $\mathrm{d}_{3}$ chromatogram and mass spectrum 


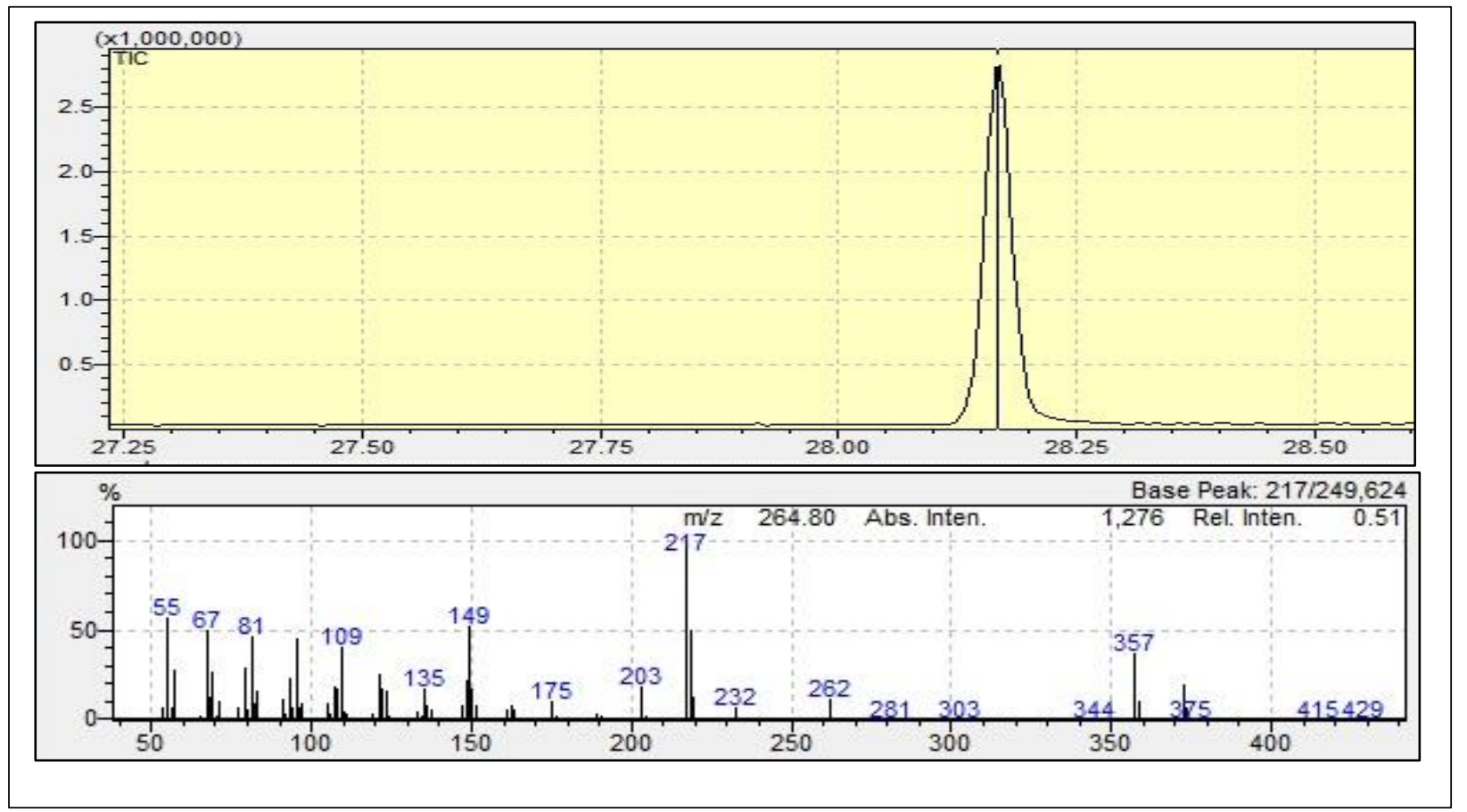

Fig. A6. 5 $\alpha$-cholestane chromatogram and mass spectrum.

\begin{tabular}{cccc}
\hline \multicolumn{3}{l}{ Table A1. Mass Spectral Properties of Compounds Used in this Study } & \\
\hline Compound & $\begin{array}{c}\text { Retention Time } \\
\text { (minutes) }\end{array}$ & Primary Ion & Secondary Ions \\
Ibuprofen & 16.225 & 161.20 & 234.25 \\
& & & 263.20 \\
Ibuprofen-d 3 & 16.195 & 163.15 & 164.20 \\
& & & 266.15 \\
5 $\alpha$-cholestane & 31.292 & 217.20 & 218.25 \\
& & 357.50 \\
\hline
\end{tabular}




\section{Appendix III. Supplementary Soil Characteristics}

\begin{tabular}{lccc}
\hline Table A2. Supplementary Soil Characteristics & Goldsboro & Norfolk & Lynchburg \\
\hline Weight/Volume Ratio & 1.42 & 1.49 & 1.55 \\
Base Saturation \% & 51 & 54 & 48 \\
Exchangeable Acidity & 1.6 & 1.6 & 1.3 \\
Phosphorus Index & 62 & 120 & 69 \\
Potassium Index & 34 & 41 & 22 \\
Sulfur Index & 40 & 32 & 31 \\
Manganese Index & 43 & 59 & 17 \\
Zinc Index & 76 & 61 & 28 \\
Copper Index & 150 & 115 & 149 \\
Exchangeable Sodium Percent & 3 & 3 & 4 \\
\hline All values were obtained from the NCDA\&CS Agronomic Division. More information on \\
reported values can be obtained at: http://www.ncagr.gov/agronomi/pdffiles/ustr.pdf \\
\hline
\end{tabular}

Table A3. Grain Size Distribution Data for Norfolk Loamy Sand

Initial Mass of Soil: $44.69(\mathrm{~g})$

\begin{tabular}{cccccc}
\hline Sieve \# & $\begin{array}{c}\text { Diameter of } \\
\text { Sieve Mesh } \\
(\mathbf{m m})\end{array}$ & $\begin{array}{c}\text { Mass of } \\
\text { Empty Sieve } \\
(\mathbf{g})\end{array}$ & $\begin{array}{c}\text { Mass of } \\
\text { Sieve + Soil } \\
\text { Retained } \\
(\mathbf{g})\end{array}$ & $\begin{array}{c}\text { Mass of Soil } \\
\text { Retained } \\
(\mathbf{g})\end{array}$ & $\begin{array}{c}\text { Percent of } \\
\text { Soil } \\
\text { Retained } \\
(\mathbf{g})\end{array}$ \\
\hline 2 & 0.25 & 262.86 & 281.92 & 19.06 & 42.71 \\
4 & 0.0635 & 319.31 & 339.00 & 19.69 & 44.12 \\
Pan & $<0.0635$ & 296.36 & 302.14 & 5.88 & 13.17 \\
& & & & Total: 44.63 & \\
\hline
\end{tabular}

Soils retained in sieve 2, 4, and pan are representative of medium-coarse sand, fine sand, and silt + clay, respectively. 
Table A4. Grain Size Distribution Data for Goldsboro Loamy Sand Initial Mass of Soil: 40.20 (g)

\begin{tabular}{cccccc}
\hline Sieve \# & $\begin{array}{c}\text { Diameter of } \\
\text { Sieve Mesh } \\
(\mathbf{m m})\end{array}$ & $\begin{array}{c}\text { Mass of } \\
\text { Empty Sieve } \\
(\mathbf{g})\end{array}$ & $\begin{array}{c}\text { Mass of } \\
\text { Sieve + Soil } \\
\text { Retained } \\
(\mathbf{g})\end{array}$ & $\begin{array}{c}\text { Mass of Soil } \\
\text { Retained } \\
(\mathbf{g})\end{array}$ & $\begin{array}{c}\text { Percent of } \\
\text { Soil } \\
\text { Retained } \\
(\mathbf{g})\end{array}$ \\
\hline 2 & 0.25 & 262.92 & 275.36 & 12.44 & 31.05 \\
4 & 0.0635 & 319.40 & 337.51 & 18.11 & 45.20 \\
Pan & $<0.0635$ & 296.42 & 305.94 & 9.52 & 23.76 \\
& & & & Total: 40.07 & \\
\hline
\end{tabular}

Soils retained in sieve 2, 4, and pan are representative of medium-coarse sand, fine sand, and silt + clay, respectively.

Table A5. Grain Size Distribution Data for Lynchburg Loamy-fine Sand Initial Mass of Soil: $42.01(\mathrm{~g})$

\begin{tabular}{|c|c|c|c|c|c|}
\hline Sieve \# & $\begin{array}{l}\text { Diameter of } \\
\text { Sieve Mesh } \\
(\mathrm{mm})\end{array}$ & $\begin{array}{c}\text { Mass of } \\
\text { Empty Sieve } \\
\text { (g) }\end{array}$ & $\begin{array}{c}\text { Mass of } \\
\text { Sieve + Soil } \\
\text { Retained } \\
\text { (g) }\end{array}$ & $\begin{array}{l}\text { Mass of Soil } \\
\text { Retained } \\
\text { (g) }\end{array}$ & $\begin{array}{l}\text { Percent of } \\
\text { Soil } \\
\text { Retained } \\
\text { (g) }\end{array}$ \\
\hline 2 & 0.25 & 289.81 & 311.02 & 21.21 & 50.74 \\
\hline 4 & 0.0635 & 224.74 & 239.86 & 15.12 & 36.17 \\
\hline Pan & $<0.0635$ & 498.32 & \multicolumn{3}{|c|}{ Total: 41.80} \\
\hline $\begin{array}{l}\text { Soils retair } \\
\text { silt + clay, }\end{array}$ & $\begin{array}{l}\text { ieve } 2,4 \text {, } \\
\text { ively. }\end{array}$ & are $r$ & & & \\
\hline
\end{tabular}


Table A6. Soil horizons in a typical Goldsboro loamy sand soil profile

\begin{tabular}{|c|c|c|}
\hline $\begin{array}{l}\text { Soil } \\
\text { Horizon }\end{array}$ & $\begin{array}{l}\text { Depth } \\
(\mathrm{cm})\end{array}$ & Description \\
\hline Ap & $0-20$ & $\begin{array}{l}\text { Grayish brown loamy sand; medium granular structure; very friable; } \\
\text { many fine roots; moderately acidic. }\end{array}$ \\
\hline $\mathrm{E}$ & $20-30$ & $\begin{array}{l}\text { Pale brown loamy sand; medium granular structure; very friable; many } \\
\text { fine roots; moderately acidic. }\end{array}$ \\
\hline $\mathrm{BE}$ & $30-38$ & $\begin{array}{l}\text { Brownish yellow sandy loam; fine subangular blocky structure; friable; } \\
\text { slightly sticky; many fine roots; strongly acidic. }\end{array}$ \\
\hline Bt1 & $38-64$ & $\begin{array}{l}\text { Yellowish brown sandy clay loam; fine subangular blocky structure; } \\
\text { friable; slightly sticky; slightly plastic; common fine roots; many clay } \\
\text { bridging between sand grains; very strongly acidic. }\end{array}$ \\
\hline $\mathrm{Bt} 2$ & $64-114$ & $\begin{array}{l}\text { Pale brown sandy clay loam; fine subangular blocky structure; friable; } \\
\text { slightly sticky; slightly plastic; few fine roots; many clay bridging } \\
\text { between sand grains; common iron depletions and masses of oxidized } \\
\text { iron; very strongly acidic. }\end{array}$ \\
\hline Btg & $114-165$ & $\begin{array}{l}\text { Gray sandy clay loam; fine subangular blocky structure; friable; slightly } \\
\text { sticky; slightly plastic; many clay bridging between sand grains; } \\
\text { common masses of oxidized iron; very strongly acidic. }\end{array}$ \\
\hline $\mathrm{BCg}$ & 114-193 & $\begin{array}{l}\text { Gray sandy loam and strata of sandy clay loam; fine subangular blocky } \\
\text { structure; friable; slightly sticky; slightly plastic; common clay bridging } \\
\text { between sand grains; common iron depletions and masses of oxidized } \\
\text { iron; very strongly acidic. }\end{array}$ \\
\hline
\end{tabular}


Table A7. Soil horizons in a typical Norfolk loamy sand soil profile

\begin{tabular}{|c|c|c|}
\hline $\begin{array}{l}\text { Soil } \\
\text { Horizon }\end{array}$ & $\begin{array}{l}\text { Depth } \\
(\mathrm{cm})\end{array}$ & Description \\
\hline Ap & $0-23$ & $\begin{array}{l}\text { Grayish brown loamy sand; fine an medium granular structure; very } \\
\text { friable; on-sticky; non-plastic; few fine and medium roots; darker- } \\
\text { colored material in old root channels; strongly acidic. }\end{array}$ \\
\hline E & $23-36$ & $\begin{array}{l}\text { Light yellowish brown loamy sand; medium granular structure; very } \\
\text { friable; non-sticky; non-plastic; few fine and medium roots; darker- } \\
\text { colored material in old root channels; strongly acidic. }\end{array}$ \\
\hline Bt1 & $36-43$ & $\begin{array}{l}\text { Yellowish brown sandy loam; medium subangular blocky structure; } \\
\text { friable; slightly sticky; slightly plastic; few fine and medium roots; } \\
\text { strongly acidic. }\end{array}$ \\
\hline $\mathrm{Bt} 2$ & $43-97$ & $\begin{array}{l}\text { Yellowish brown sandy clay loam; medium subangular blocky } \\
\text { structure; friable; slightly sticky; slightly plastic; many fine and medium } \\
\text { pores; strongly acidic. }\end{array}$ \\
\hline Bt3 & $97-147$ & $\begin{array}{l}\text { Yellowish brown sandy clay loam; medium subangular blocky } \\
\text { structure; friable; slightly sticky; slightly plastic; few masses of oxidized } \\
\text { iron and few iron depletions; strongly acidic. }\end{array}$ \\
\hline Bt4 & $147-178$ & $\begin{array}{l}\text { Yellowish brown sandy clay loam; medium subangular blocky } \\
\text { structure; friable; slightly sticky; slightly plastic; masses of oxidized } \\
\text { iron and few iron depletions; strongly acidic. }\end{array}$ \\
\hline $\mathrm{BC}$ & $178-208$ & $\begin{array}{l}\text { Sandy clay loam; medium subangular blocky structure; friable; slightly } \\
\text { sticky; slightly plastic; strongly acidic. }\end{array}$ \\
\hline $\mathrm{C}$ & $208-254$ & $\begin{array}{l}\text { Sandy clay loam; massive; slightly sticky; slightly plastic; strongly } \\
\text { acidic. }\end{array}$ \\
\hline
\end{tabular}


Table A8. Soil horizons in a typical Lynchburg loamy fine sand soil profile

\begin{tabular}{|c|c|c|}
\hline $\begin{array}{c}\text { Soil } \\
\text { Horizon }\end{array}$ & $\begin{array}{l}\text { Depth } \\
(\mathrm{cm})\end{array}$ & Description \\
\hline Ap & $0-15$ & $\begin{array}{l}\text { Very dark gray loamy fine sand; medium granular structure; very } \\
\text { friable; common fine roots; few medium roots; very strongly acidic. }\end{array}$ \\
\hline $\mathrm{E}$ & $15-25$ & $\begin{array}{l}\text { Light olive brown loamy fine sand; medium subangular blocky } \\
\text { structure; very friable; common fine roots; few fine pores; common iron } \\
\text { depletions; very strongly acidic. }\end{array}$ \\
\hline $\mathrm{Bt}$ & $25-43$ & $\begin{array}{l}\text { Light olive brown sandy clay loam; medium subangular blocky } \\
\text { structure; friable; common fine roots; few fine pores; common iron } \\
\text { depletions and many masses of oxidized iron; very strongly acidic. }\end{array}$ \\
\hline Btg1 & $43-76$ & $\begin{array}{l}\text { Light brownish gray sandy clay loam; medium subangular blocky } \\
\text { structure; friable; few fine roots; few fine pores; common iron } \\
\text { depletions and many masses of oxidized iron; very strongly acidic. }\end{array}$ \\
\hline Btg2 & $76-165$ & $\begin{array}{l}\text { Gray sandy clay loam; medium subangular blocky structure; friable; few } \\
\text { fine roots; masses of oxidized iron; strongly acidic. }\end{array}$ \\
\hline Btg3 & $165-203$ & $\begin{array}{l}\text { Gray clay; medium subangular structure; firm; few fine roots; masses of } \\
\text { oxidized iron and iron depletions; strongly acidic. }\end{array}$ \\
\hline
\end{tabular}




\section{Appendix IV. Supplementary Batch Treatment Data}

Table A9. Data Obtained for Analysis of Particulate Organic Carbon (POC) in Batch Treatments

\begin{tabular}{cccccc}
\hline Sample ID & $\begin{array}{c}\text { Filter Tare } \\
\text { Weight } \\
(\mathbf{g})\end{array}$ & $\begin{array}{c}\text { Weight of } \\
\text { Filter + Dry } \\
\text { Wight of } \\
\text { Sample } \\
(\mathbf{g})\end{array}$ & $\begin{array}{c}\text { Dry Weight } \\
\text { of Sample on } \\
\text { Filter } \\
(\mathbf{g})\end{array}$ & $\begin{array}{c}\text { Post } \\
\text { Combustion } \\
\text { Weight } \\
\mathbf{( g )}\end{array}$ & $\begin{array}{c}\text { Mass of } \\
\text { POC } \\
(\mathbf{m g})\end{array}$ \\
\hline Goldsboro 1 & 0.1108 & 0.2461 & 0.1353 & 0.2197 & 26.40 \\
Goldsboro 2 & 0.1119 & 0.2257 & 0.1138 & 0.2056 & 20.10 \\
Norfolk 1 & 0.1107 & 0.2084 & 0.0977 & 0.1916 & 16.80 \\
Norfolk 2 & 0.1111 & 0.2088 & 0.0977 & 0.1908 & 18.00 \\
Lynchburg 1 & 0.1117 & 0.2053 & 0.0936 & 0.1884 & 16.90 \\
Lynchburg 2 & 0.1117 & 0.2137 & 0.1020 & 0.1947 & 19.00 \\
\hline
\end{tabular}

Batch treatments used to determine the POC of the aqueous phase were performed in duplicate. Samples were processed using the combustion method.

Table A10. Data Obtained for Analysis of Dissolved Organic Carbon (DOC) and Total Dissolved Nitrogen (TDN) in Batch Treatments

\begin{tabular}{ccc}
\hline Sample ID & $\begin{array}{c}\text { DOC } \\
(\mathbf{m g ~ L}\end{array}$ & $\begin{array}{c}\text { TDN } \\
\left(\mathbf{m g ~ L}^{-1}\right)\end{array}$ \\
\hline Goldsboro 1 & 9.097 & 0.9745 \\
Goldsboro 2 & 8.629 & 0.9437 \\
Norfolk 1 & 10.44 & 1.441 \\
Norfolk 2 & 10.74 & 1.438 \\
Lynchburg 1 & 9.788 & 0.7519 \\
Lynchburg 2 & 9.915 & 0.7566 \\
\hline
\end{tabular}

Batch treatments used to determine the DOC/TDN of the aqueous phase were performed in duplicate. Analysis was performed on a Shimadzu TOC- $\mathrm{V}_{\mathrm{CPN}}$ with TNM-1 analyzer.

\begin{tabular}{cccc}
\hline Table A11. Data Obtained for Analysis of Aqueous pH of Batch Treatments \\
\hline Sample ID & $\begin{array}{c}\text { Mass of Soil } \\
(\mathbf{g})\end{array}$ & $\begin{array}{c}\text { Volume of Water } \\
(\mathbf{m L})\end{array}$ & $\mathbf{p H}$ \\
\hline Norfolk 1 & 7.2241 & 17.7740 & 5.36 \\
Norfolk 2 & 6.5937 & 23.4404 & 5.32 \\
Norfolk 3 & 6.2253 & 20.1409 & 5.40 \\
Goldsboro 1 & 6.8561 & 19.5546 & 5.51 \\
Goldsboro 2 & 8.7639 & 19.9701 & 5.37 \\
Goldsboro 3 & 8.2172 & 22.3612 & 5.42 \\
Lynchburg 1 & 6.1457 & 21.4556 & 6.35 \\
Lynchburg 2 & 8.2427 & 19.6747 & 7.00 \\
Lynchburg 3 & 7.0924 & 20.6658 & 6.41 \\
\hline
\end{tabular}

All values were obtained using a Corning $430 \mathrm{pH}$ meter. 


\begin{tabular}{|c|c|c|c|c|c|}
\hline Soil & $\begin{array}{c}C_{s} \\
\left(\mu \mathrm{g} \mathrm{kg}^{-1}\right)\end{array}$ & $\begin{array}{c}C_{w} \\
\left(\mu g L^{-1}\right)\end{array}$ & $\begin{array}{c}\mathrm{K}_{\mathrm{d}} \\
\left(\mathrm{L} \mathrm{kg}^{-1}\right)\end{array}$ & $\begin{array}{c}\mathrm{K}_{\mathrm{oc}} \\
\left(\mathrm{L} \mathrm{kg}^{-1}\right)\end{array}$ & $\begin{array}{c}\log K_{o c} \\
\left(\mathrm{~L} \mathrm{~kg}^{-1}\right)\end{array}$ \\
\hline Goldsboro & 244.76 & 222.56 & 1.10 & 139.21 & 2.14 \\
\hline Goldsboro & 385.46 & 198.72 & 1.94 & 245.54 & 2.39 \\
\hline Goldsboro & 896.38 & 941.38 & 0.95 & 120.53 & 2.08 \\
\hline Goldsboro & 1257.48 & 1185.15 & 1.06 & 134.31 & 2.13 \\
\hline Norfolk & 10.20 & 40.75 & 0.25 & 67.65 & 1.83 \\
\hline Norfolk & 283.23 & 318.35 & 0.89 & 240.45 & 2.38 \\
\hline Norfolk & 555.12 & 719.61 & 0.77 & 208.49 & 2.32 \\
\hline Norfolk & 890.40 & 1213.77 & 0.73 & 198.27 & 2.30 \\
\hline Lynchburg & 293.99 & 2071.96 & 0.14 & 70.95 & 1.85 \\
\hline Lynchburg & 719.44 & 392.89 & 1.83 & 915.56 & 2.96 \\
\hline Lynchburg & 396.90 & 1521.38 & 0.26 & 130.44 & 2.12 \\
\hline Lynchburg & 289.99 & 1545.60 & 0.19 & 93.81 & 1.97 \\
\hline Lynchburg & 566.34 & 2060.11 & 0.27 & 137.45 & 2.14 \\
\hline Lynchburg & 1223.95 & 1143.72 & 1.07 & 535.07 & 2.73 \\
\hline
\end{tabular}

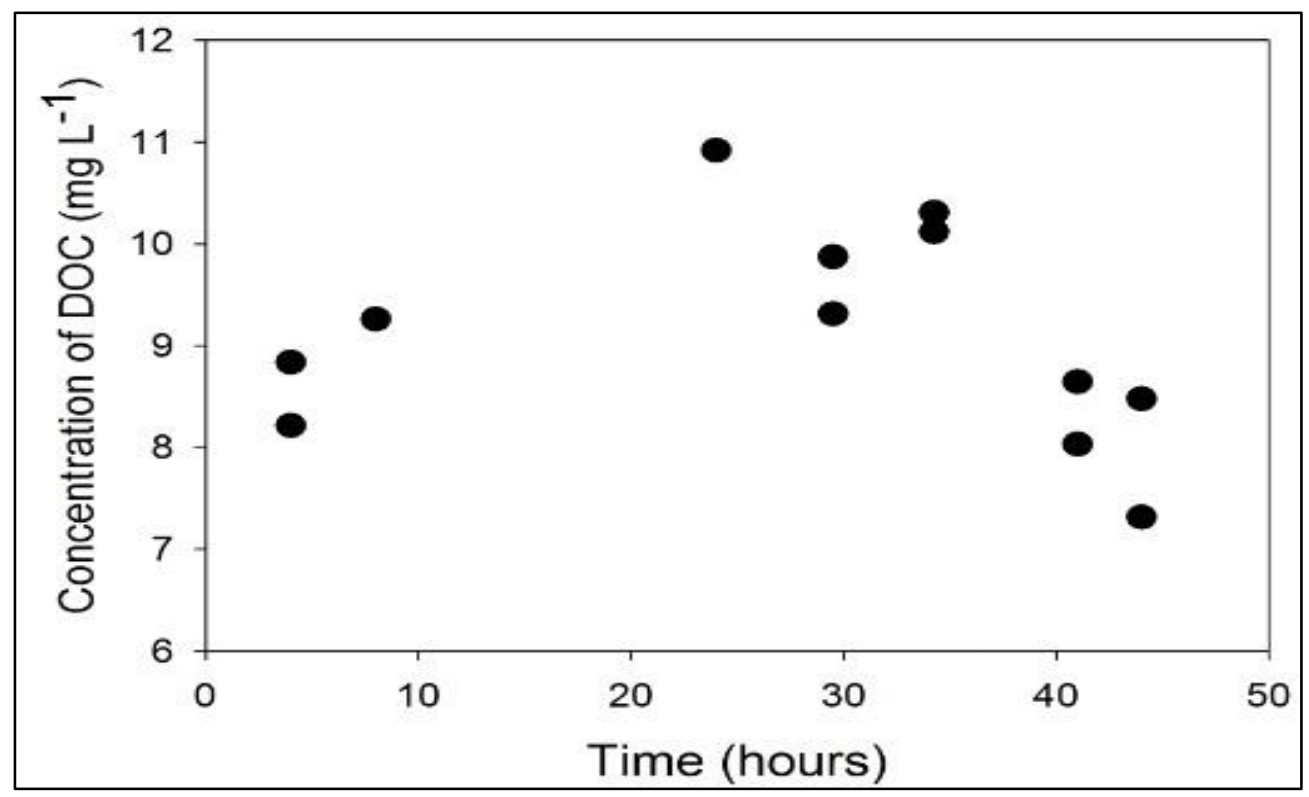

Fig. A7. Aqueous-phase DOC over time in a preliminary batch experiment used to determine amount of time necessary for the soil/water mixture to reach equilibrium. Agitation of test tubes was ceased after 4, 8, 12, 24, 30, 36,41 , and 44 hours and filtered through $0.47-\mathrm{mm}$ glass fiber filters to remove particulates. Analysis of DOC was performed on a Shimadzu TOC$\mathrm{V}_{\text {CPN. }}$. 


\section{Appendix V. Calculation of Ibuprofen in Aqueous and Solid Matrices}

\section{All calculations were performed in excel.}

\section{Step 1.}

To determine the relative response factor (RRF) of ibuprofen- $\mathrm{d}_{3}$ (surrogate standard) to $5 \alpha$ cholestane (internal standard), a solution containing both compounds, including the target compound, was injected into the GC-MS. The following equation was used to calculate the RRF of surrogate to internal:

$\mathrm{RRF}=(\mathrm{M} / \mathrm{A}) /\left(\mathrm{M}_{1} / \mathrm{A}_{1}\right)$

where $\mathrm{M}$ and $\mathrm{M}_{1}$ are the mass of surrogate and internal compound injected into the $\mathrm{GC}$, respectively; $\mathrm{A}$ and $\mathrm{A}_{1}$ are the peak area of the surrogate and internal, respectively. To determine the RRF of ibuprofen (target compound) to the surrogate, the following equation was used:

$\mathrm{RRF}=(\mathrm{M} / \mathrm{A}) /\left(\mathrm{M}_{1} / \mathrm{A}_{1}\right)$ where $\mathrm{M}$ and $\mathrm{M}_{1}$ are the mass of target and surrogate compound injected into the GC, respectively; $\mathrm{A}$ and $\mathrm{A}_{1}$ are the peak area of the target and surrogate compound, respectively. It is important to note that an RRF standard was injected into the GC on each day that extracts from batch treatments were analyzed to ensure that instrument was giving consistent peak areas for the compounds of interest.

\section{Step 2.}

Next, for each batch treatment, the mass of ibuprofen- $\mathrm{d}_{3}, 5 \alpha$-cholestane, and ibuprofen were entered into the excel spreadsheet, along with their respective concentrations, and peak areas detected by the MS. This data, along with the RRF previously mentioned was used to calculate the percent of ibuprofen- $\mathrm{d}_{3}$ recovered during extraction as well as the concentration of ibuprofen 
in the aqueous phase of each batch treatment. The percent recovery of ibuprofen- $\mathrm{d}_{3}$ calculated from batch experiments is explained by the following equation:

$\%$ Recovery of ibuprofen- $\mathrm{d}_{3}=(\mathrm{C} / \mathrm{D}) \times 100$

where $\mathrm{C}$ is the calculated mass of ibuprofen- $\mathrm{d}_{3}$ recovered after extraction, and $\mathrm{D}$ is the mass of ibuprofen- $d_{3}$ initially injected into the aqueous phase of batch treatment. The percent recovery of the surrogate standard was used for $\mathrm{QA} / \mathrm{QC}$ purposes since it is chemically similar to the target compound

The following equation explains how the mass of ibuprofen extracted from the aqueous phase of batch treatments was calculated:

Mass of ibuprofen in aqueous phase $=(\mathrm{E} / \mathrm{F}) \times \mathrm{G} \times \mathrm{H}$

where $\mathrm{E}$ is the mass of ibuprofen added to the aqueous phase of treatments, $\mathrm{F}$ is the peak area of the surrogate compound detected by the MS, G is the peak area of the target compound detected by the MS, and $\mathrm{H}$ is the RRF of ibuprofen to ibuprofen- $\mathrm{d}_{3}$.

\section{Step 3.}

To calculate the concentration of ibuprofen in the aqueous phase, the calculated mass was divided by the volume of water used in the respective batch treatment.

\section{Step 4.}

To calculate the concentration of ibuprofen in the aqueous phase assuming $100 \%$ recovery, the following equation was employed:

Concentration of ibuprofen in aqueous phase (assuming $100 \%$ recovery) $=(1 / \mathrm{X}) \times 100 \times \mathrm{Z}$ where $\mathrm{X}$ is the percent recovery and $\mathrm{Z}$ is the concentration of ibuprofen calculated in step 3 . 
The calculation of ibuprofen in the solid phase was determined using the same procedure and calculations, except that in step 3, the calculated mass of ibuprofen (in the solid phase), was divided by the mass of soil used in the respective batch treatment. 
